\title{
Additional Data on the Fauna of Bivalve Mollusks of the Russian Continental Coast of the Sea of Japan : Middle Primorye and Nakhodka Bay
}

\author{
$\operatorname{AUTHOR}(\mathrm{S}):$ \\ Lutaenko, Konstantin A.
}

\section{CITATION:}

Lutaenko, Konstantin A.. Additional Data on the Fauna of Bivalve Mollusks of the Russian Continental Coast of the Sea of Japan: Middle Primorye and Nakhodka Bay.

PUBLICATIONS OF THE SETO MARINE BIOLOGICAL LABORATORY 1999, 38(5-6): 255-286

ISSUE DATE:

1999-09-30

URL:

http://hdl.handle.net/2433/176283

RIGHT: 


\title{
Additional Data on the Fauna of Bivalve Mollusks of the Russian Continental Coast of the Sea of Japan: Middle Primorye and Nakhodka Bay
}

\author{
Konstantin A. Lutaenko \\ The Institute Museum, Institute of Marine Biology, Far East Branch \\ of the Russian Academy of Sciences, Vladivostok 690041, Russia
}

\begin{abstract}
The bivalve molluscan fauna of Vrangel Bay, a small embayment in the eastern part of Peter the Great Bay (Nakhodka Bay), and in several localities along the coast of middle Primorye (Maritime Province, both in north-western part of the Sea of Japan, was studied based on 185 dredge and SCUBA-diving samples (in all, 40 stations). A total of 58 species of bivalves were identified. Eight species are recorded for the first time from the coast of middle Primorye. Comparative analysis of bathymetric ranges of bivalve mollusks from different parts of the Sea of Japan is carried out, and presence of shells believed to be subfossil and redeposition of Recent shell remains are discussed. Cold-water and relatively cold-water mollusks occur in Vrangel Bay, a protected bay, in shallow waters which can be explained by the influence of the cold Primorskoe Current. The faunal differences between eastern and western parts of Peter the Great Bay are emphasized. Taxonomic and biogeographic comments on some species are given.
\end{abstract}

Key words: bivalve mollusks, biogeography, batymetric ranges, taxonomy

\section{Introduction}

Despite the appearance of the monograph of Scarlato (1981) dealing with bivalve fauna of all Russian (former Soviet) Far Eastern Seas, and a number of recent publications, species composition, taxonomy and distributional patterns of bivalve mollusks of the Russian part of the Sea of Japan (East Sea) remain poorly known as compared to the Japanese coast. Peter the Great Bay (the southern part of the Primorye Territory, Maritime Province is the only thoroughly investigated area; however, species composition data and distribution of mollusks refer mostly to some bays and localities within Peter the Great Bay -Possjet Bay (Golikov \& Scarlato, 1967; 1971), Far East State Marine Reserve area (Moskaletz, 1984; 1990), and Vostok Bay (Evseev, 1976). There are also several papers describing selected bivalves from Peter the Great Bay or treating their nomenclature and systematics based on materials mainly from the Bay (Bartsch, 1929; Scarlato, 1972; Ivanova \& Moskaletz, 1984; Lutaenko, 1993; Kafanov \& Lutaenko, 1996, 1997a, b; Kamenev, 1996). We undertook a special faunal and taphonomic investigation on beach molluscan thanatocoenoses in Possjet, Amur, Ussuri and Vostok Bays (Lutaenko, 1990; 1994a, b).

As for the areas situated north of Peter the Great Bay, we should mention a paper of Romeyko (1985). Unfortunately, this author performed only a biogeographical and ecological analysis of bivalve fauna, without presentation of species lists. Therefore, we are not able to define the exact geographical distributions of many species along the Russian continental part of the Sea of Japan or to compile species lists for each coastal area or bay. These gaps can be filled only by Scarlato (1981) data, but they are outdated and additional faunal studies are needed.

The bivalve fauna of the southern part of Sakhalin Island (Golikov \& Scarlato, 1985) and small Moneron Island in the north-western part of the Sea of Japan (Ivanova, 1985; Romeyko \& Kamenev, 1985) were studied more completely due to the work of hydrobiological 


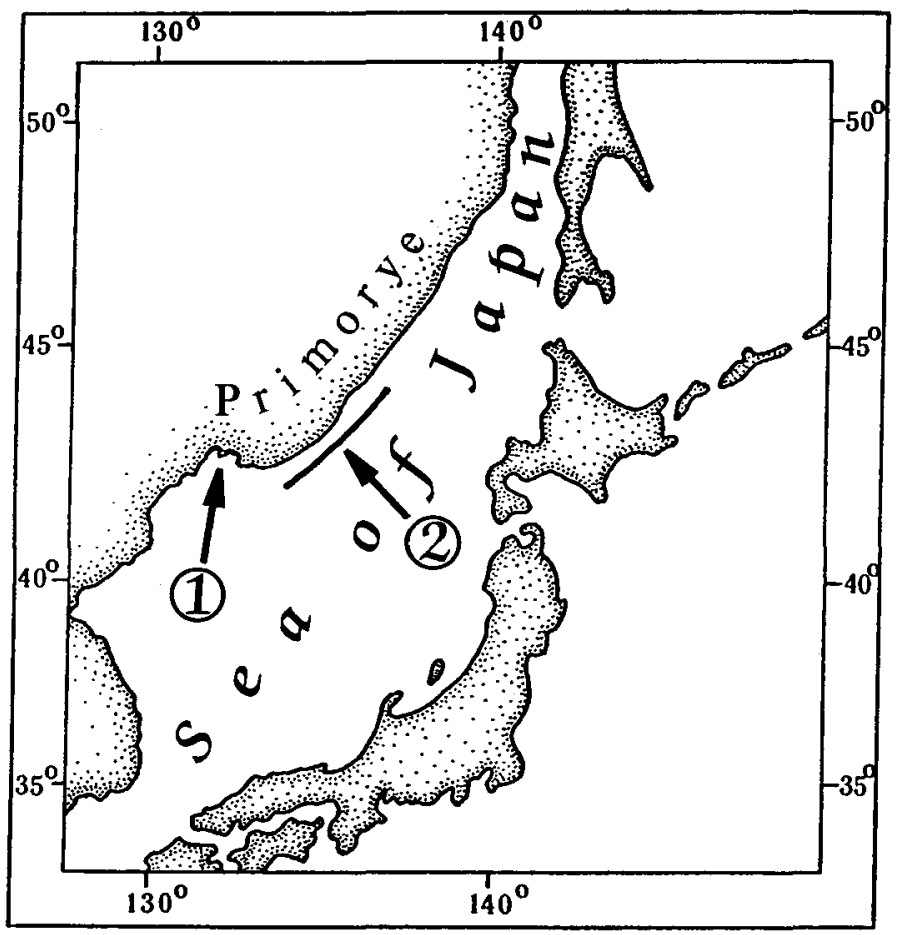

Fig. 1. Map of the Sea of Japan with areas of collecting mollusks (1 - Peter the Great Bay, 2 - middle Primorye coast).

teams of the Institute of Marine Biology, Far East Branch of the Russian Academy of Sciences (former USSR Academy of Sciences) during the 1970's and 1980's. Evseev (1981) described in detail the Holocene history of bivalve molluscan fauna of the middle part of Primorye Territory, but some species names given in his work are without decriptions or illustrations and require a taxonomical and nomenclatural revision. The present paper deals with new materials on the species composition, distribution and habitats of bivalve mollusks in two areas: Vrangel Bay and middle Primorye (Fig. 1). Vrangel Bay is situated within Nakhodka Bay - one of the largest embayments inside Peter the Great Bay, but bivalve mollusks have not been studied in this area except for the records of some commercial species (Razin, 1934). Biogeographically, middle Primorye is located in another unit in terms of zonal biogeography (Scarlato, 1981) and environmental conditions are quite different from Peter the Great Bay.

\section{Materials and Methods}

Materials for this study were collected in Vrangel Bay during August 1995 aboard the R/V Kassis (24 stations) (Fig. 2) and along the coast of middle Primorye (Figs. 3-5) during September-October 1995 aboard the R/V Akademik Oparin, 18th cruise (16 stations). A total of 185 samples were treated containing both empty shells and live mollusks. Living specimens were fixed with $70 \%$ ethanol (middle Primoryie) or formalin (Vrangel Bay). In Vrangel Bay samples were collected using a small dredge and simultaneously, at the same stations, with a bottom-sampler by SCUBAdivers. During the 18th cruise of the $R / V$ Akademik Oparin, samples were collected qualitatively by SCUBA-divers and by the same dredge. One station was sampled by trawl (sta. 39). At a majority of SCUBA-diving stations, benthic organisms were collected at different depths and bottom 

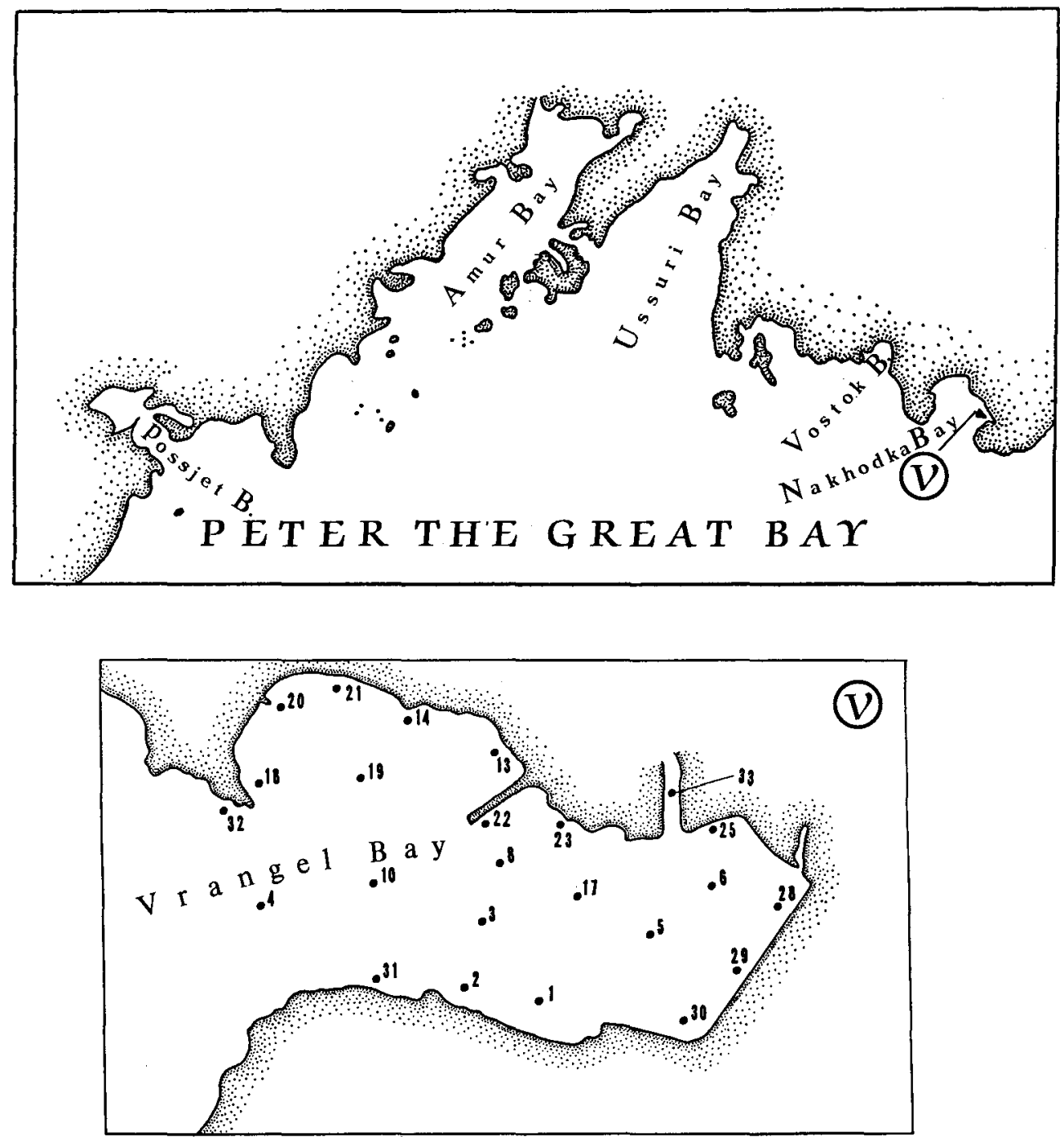

Fig. 2. Map of Peter the Great Bay with sampling stations in Vrangel Bay (V: Vrangel Bay).

types, and, in this case, several samples were taken at one station. The samples were sieved on board of the ship and sorted into dead (empty shells) and live specimens. Samples from Vrangel Bay were first fixed aboard ship and then sieved in the laboratory of the Institute Museum, Institute of Marine Biology, FEB RAS. The majority of live mollusks were dried after a fixation period of $2-4$ months.

The collection of bivalve mollusks from both areas studied is stored in the Institute Museum, Institute of Marine Biology, FEB RAS.

Abbreviations used throughout the text are as follows: MIMB - the Institute Museum, Institute of Marine Biology, FEB RAS (Vladivostok); ZMFU - Zoological Museum, Far East State University (Vladivostok); M.e. - material examined; s. - specimen(s).

\section{Regional Setting}

The Russian continental coast of the Sea of Japan is clearly divided into two geomorphological 
258

K.A. Lutaenko

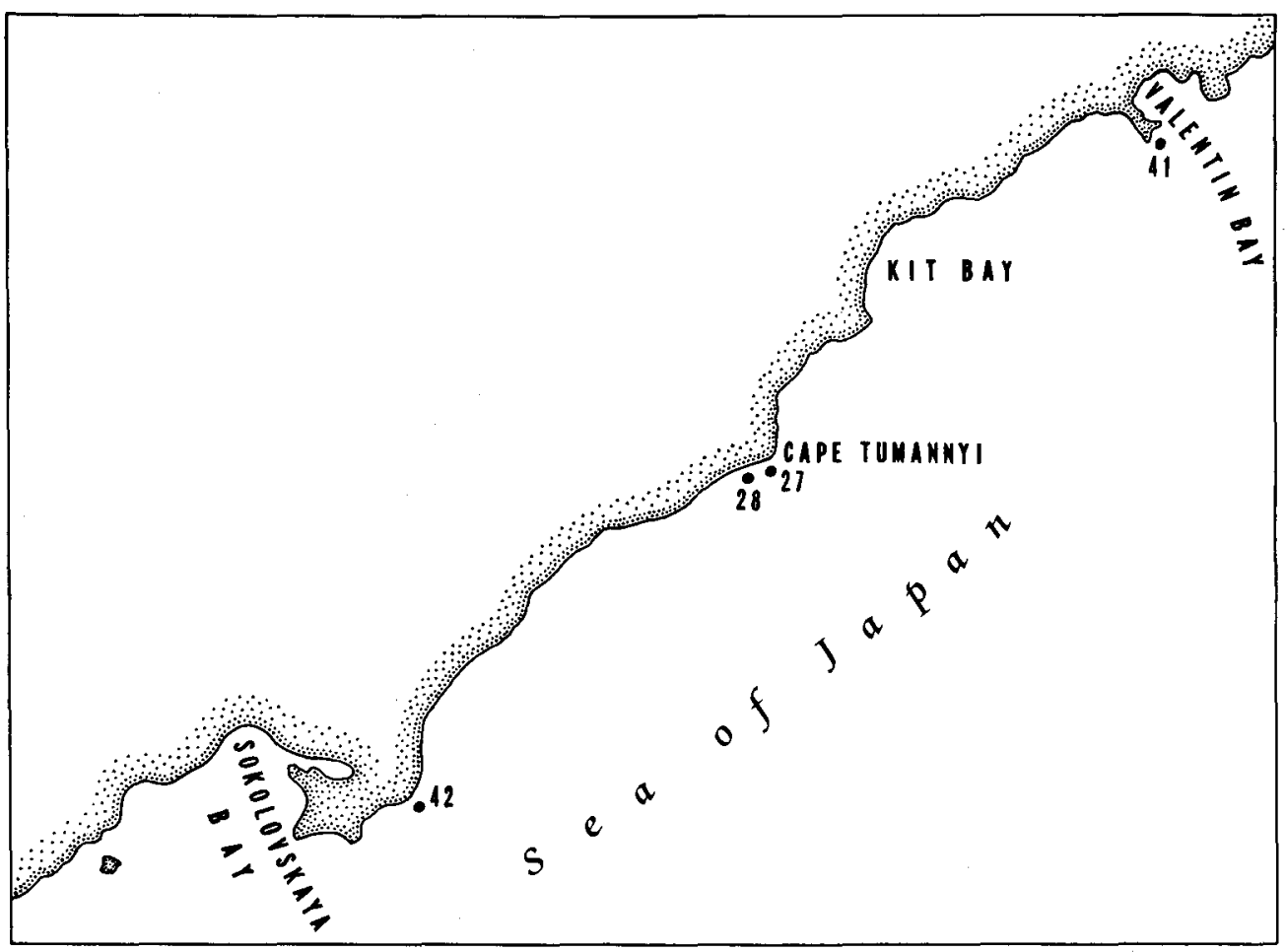

Fig. 3. Map of the middle Primorye with sampling stations 27, 28, 41, 42 (southern part of the area studied).

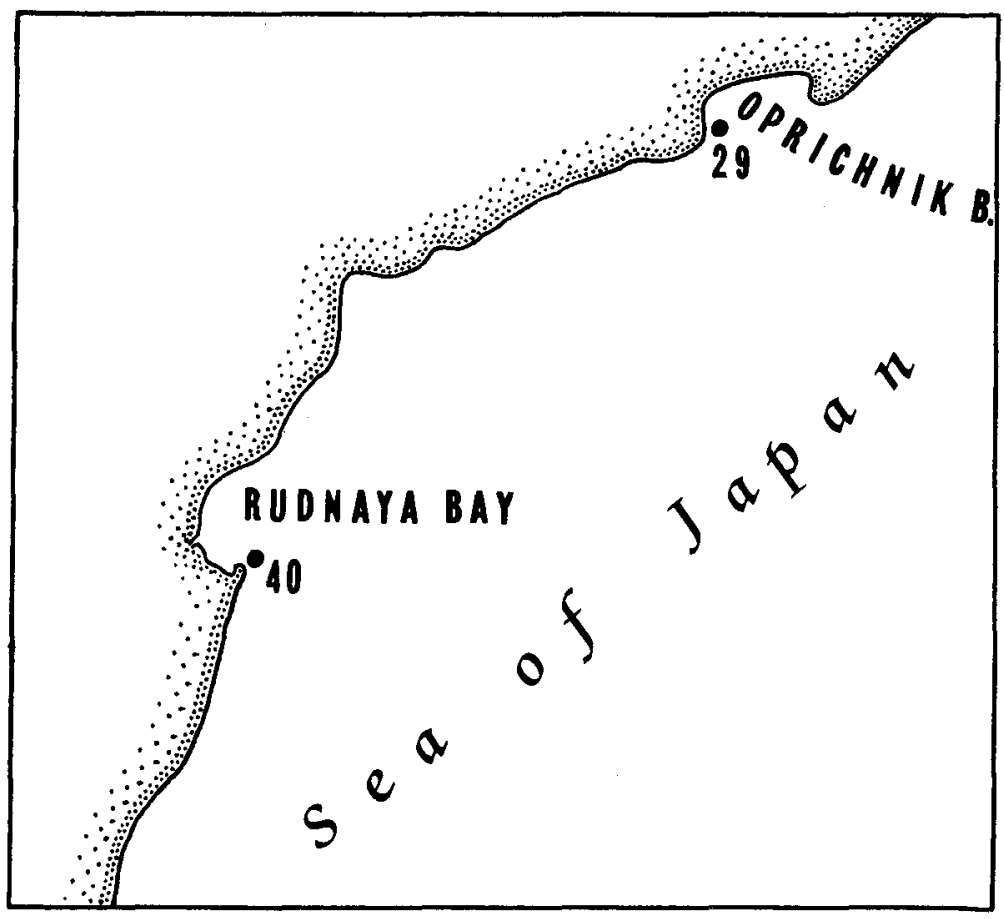

Fig. 4. Map of the middle Primorye with sampling stations 9, 40 (northern part of the area studied). 
Table 1. Sampling stations of the $\mathrm{R} / \mathrm{V}$ Akademik Oparin made in middle Primorye (Maritime Province) during 18th cruise (September - October 1995).

\begin{tabular}{crc}
\hline STATION & LATITUDE, N & LONGITUDE, W \\
\hline 27 & $42^{\circ} 58^{\prime}$ & $134^{\circ} 06^{\prime}$ \\
28 & $42^{\circ} 58^{\prime}$ & $134^{\circ} 06^{\prime}$ \\
29 & $44^{\circ} 26^{\prime}$ & $135^{\circ} 59^{\prime}$ \\
30 & $44^{\circ} 26^{\prime}$ & $135^{\circ} 59^{\prime}$ \\
31 & $44^{\circ} 26^{\prime}$ & $135^{\circ} 59^{\prime}$ \\
32 & $44^{\circ} 32^{\prime}$ & $136^{\circ} 11^{\prime}$ \\
33 & $44^{\circ} 34^{\prime}$ & $136^{\circ} 13^{\prime}$ \\
34 & $44^{\circ} 44^{\prime}$ & $136^{\circ} 20^{\prime}$ \\
35 & $44^{\circ} 46^{\prime}$ & $136^{\circ} 27^{\prime}$ \\
36 & $44^{\circ} 47^{\prime}$ & $136^{\circ} 19^{\prime}$ \\
37 & $44^{\circ} 56^{\prime}$ & $136^{\circ} 34^{\prime}$ \\
38 & $44^{\circ} 55^{\prime}$ & $136^{\circ} 33^{\prime}$ \\
39 & $44^{\circ} 51^{\prime}$ & $136^{\circ} 37^{\prime}$ \\
40 & $*$ & $*$ \\
41 & $43^{\circ} 05^{\prime} * *$ & $134^{\circ} 18^{\prime} * *$ \\
42 & $42^{\circ} 53^{\prime}$ & $133^{\circ} 97^{\prime}$ \\
\hline$*$ & &
\end{tabular}

regions with different hydrological regimes and environmental conditions. The northern region is characterized by a weakly indented coastline with openbays representing, in most cases, concavities of the coast, not sheltered from winds. Abrasional shores with rocky cliffs of significant height and comparatively narrow gravel and boulder beaches predominate along nearly the entire coastline; accumulative areas (low marine terraces) occur in coastal concavities (Papunov, 1987).

Bays, relatively enclosed from wind waves and cut into the coast (Plastun, Dzhigit, Olga, Vladimir, Valentin Bays, etc.), were formed by the ingression of the sea into erosional river valleys (Ignatova \& Chudaeva, 1983; Korotky \& Khudyakov, 1990). A large number of small streams originating from mountain slopes and several large rivers flow into the sea in this area, but do not significantly influence the hydrological conditions of the shallow waters.

The northern shelf of the Sea of Japan is narrow (average $35 \mathrm{~km}$ ), and occasionally narrows to only $10-11 \mathrm{~km}$. The depth of the shelf edge varies from 100 to $200 \mathrm{~m}$. Coarse-grained sand and pebble deposits that accumulated during the maximum of last glaciation, when the sea level dropped 120-130 m (Korotky et al., 1980), are distributed along the marginal areas of the shelf. In the upper part of the shelf, basal rocks are frequently found with thin layers of clastic deposits (Ignatova \& Chudaeva, 1983). Sandy sediments are limited in their distribution along the coast of middle Primorye. Silty sands are found in the wide area of the central shelf, sometimes having an admixture of pebbles. Muddy sediments occupy the bottom of semi-enclosed bays.

Two cold currents wash the coast of Primorye - Primorskoe (Maritime Province Cold Current, according to Hidaka, 1966) and Schrenck Currents (= Liman Cold Current) (Yurasov \& Yarichin, 1991). The main stream of Primorskoe Current flows at a distance of $15-20 \mathrm{~km}$ from the coast along the marginal part of the shelf and mainly below $50-60 \mathrm{~m}$. In the upper part of the shelf (above $20 \mathrm{~m}$ ), there is a compensating anti-current of warm water; in this bathymetric range, water can warm to $15-17^{\circ} \mathrm{C}$ (Evseev, 1981). Generally, cold currents in the Sea of Japan are much weaker than warm currents (Hidaka, 1966). Salinity in open areas approaches normal marine and is $33-34 \%$ in the zone affected by the Primorskoe Current, but it can decrease in bays for a short 


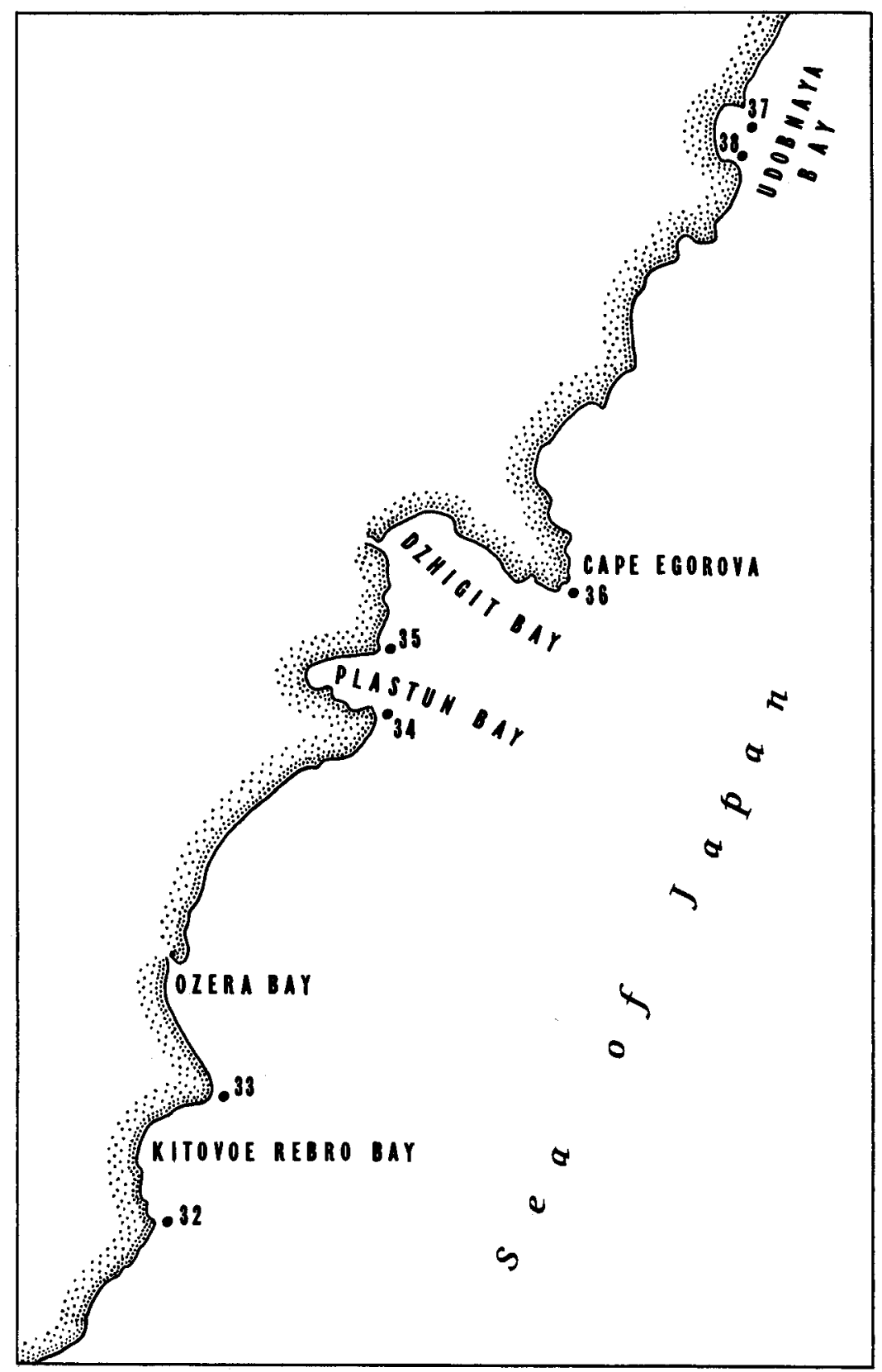

Fig. 5. Map of the middle Primorye with sampling stations 32- 38 (most northern part of the area studied).

time during periods of rains.

The southern geomorphological area includes Peter the Great Bay with six large embayments - Possjet, Amur, Ussuri, Strelok, Vostok, and Nakhodka Bays. Vrangel Bay is located on the eastern coast of Nakhodka Bay and is strongly influenced by anthropogenic pressure due to the activity of Port Vostochny. The temperature regime of Peter the Great Bay is characterized by the contrasting conditions. During winter, coastal waters become equal in temperature approaching arctic 
conditions. During summer, waters of semi-enclosed shallow bays warm strongly (to $28^{\circ} \mathrm{C}$ in August) (Biryulin et al., 1970). At the same time, in the subtidal zone of open areas, August temperatures reach $15-17^{\circ} \mathrm{C}$.

Salinity of the surface waters depends significantly on river runoff. During the summer, upper layers 10-15 m thick may have low salinity due to typhoons and rain but these layers of unstable salinity are rapidly destroyed by wave action (Podorvanova et al., 1989). In winter, salinity seems to be equal in all areas of Peter the Great Bay. Bottom deposits in Vrangel Bay are represented mainly by mud and muddy sand in central parts of the bay, and by sand and gravel near coastline (Rynkov et al., 1974).

\title{
SYSTEMATIC ACGOUNT
}

\author{
Class Bivalvia \\ Subclass Protobranchia \\ Superfamily Nuculoidea Gray, 1824 \\ Family Nuculidae Gray, 1824
}

Nucula (Ennucula) ovatotruncata (Scarlato in Volova et Scarlato, 1980)

Records. Vrangel Bay: sta. 5, 10, 13, 16, 19, 30, 33.

Occurrence. This species was found at a bathymetric range of $4.5-17.5 \mathrm{~m}$, in sandy and muddy sediments.

M.e. 10 s.

\section{Acila (Truncacila) insignis (Gould, 1861)}

Records. Vrangel Bay: sta. 14, 23.

Occurrence. One live specimen was taken in $4-6 \mathrm{~m}$, in sand. Empty shell is found at a depth of $7.5 \mathrm{~m}$, on rocky bottom.

M. e. 2 s.

Superfamily Nuculanoidea H. Adams et A. Adams, 1858

Family Nuculanidae H. Adams et A. Adams, 1858

Subfamily Nuculaninae H. Adams et A. Adams, 1858

Nuculana (Nuculana) sadoensis) (Yokoyama, 1926)

Records. Middle Primorye: sta. 39. pebbles.

Occurrence. One live specimen was taken in $111 \mathrm{~m}$, in muddysand with

M. e. $1 \mathrm{~s}$.

Subfamily Yoldiinae Habe, 1977

Yoldia (Cnesterium) johanni Dall, 1925

Records. Vrangel Bay: sta. 13; middle Primorye: sta. 41.

Occurrence. It was taken in Vrangel Bay in $4.5 \mathrm{~m}$, in sand, and near Cape Titova in middle Primorye this species was found in $15 \mathrm{~m}$.

Remarks. Scarlato (1981) noted that $Y$. johanni inhabits the Sea of Japan, northern Japan and the southern Kuril Islands (Iturup Island). Matsukuma et al. (1991) also mentioned western coast of the Kamchatka Peninsula $\left(54^{\circ} 30^{\prime} \mathrm{N}, 155^{\circ} 00^{\prime} \mathrm{E}\right)$ as the northernmost locality based on Ito (1966; non vidi) record. 
M. e. 2 s.

\section{Yoldia (Cnesterium) notabilis Yokoyama, 1922}

Records. Vrangel Bay: sta. 1-4, 10, 17, 30.

Occurrence. Live mollusks were taken in muddy sand and mud in a depth range of $10-17.5 \mathrm{~m}$; one empty shell was collected in $16.5 \mathrm{~m}$, in sand.

Remarks. This species was described by Scarlato (1981) as a new subspecies, Yoldia (Cnesterium) keppeliana pseudonotabile (holotype originated from Nakhodka Bay). Kafanov (1991) stated that part of specimens of Y. keppeliana pseudonotabile in Scarlato's collection refers to Yoldia (Cnesterium) keppeliana Sowerby, 1904, but mostly to Y. notabilis.

M. e. $7 \mathrm{~s}$.

Subclass Pterimorphia

Superfamily Mytiloidea Rafinesque, 1815

Family Mytilidae Rafinesque, 1815

Subfamily Mytilinae Rafinesque, 1815

Crenomytilus grayanus (Dunker, 1853)

Records. Vrangel Bay: sta. 31; middle Primorye: sta. 29, 34-36, 42.

Occurrence. Empty shells of this common mussel were found among sand and pebbles in Vrangel Bay, at a depth $7 \mathrm{~m}$. Live mollusks were collected in Oprichnik, Plastun, Dzhigit, and Sokolovskaya Bays in total bathymetric range of $0.5-12 \mathrm{~m}$, on rocky bottom and among seagrass Phyllospadix iwatensis.

M. e. 27 s.

\section{Mytilus (Mytilus) edulis L., 1758 s.1.}

Records. Vrangel Bay: sta. 6, 30, 33.

Occurrence. Empty shells were taken in $7.5-25 \mathrm{~m}$, in muddy sand and mud.

M. e. 3 s.

Subfamily Crenellinae Gray, 1840

\section{Vilasina pillula Bartsch in Scarlato, 1960}

Records. Middle Primorye: sta. 29, 30, 32, 34-38, 41.

Occurrence. This species was taken in Oprichnik, Kitovoe Rebro, Plastun, Dzhigit, and Udobnaya Bays, and near Cape Titova in total depth range of $0.5-20 \mathrm{~m}$, on rocky bottom, occasionally among seagrass Phyllospadix iwatensis and in the belt of algae Tichocarpus.

Remarks. The species is recorded for the coast of middle Primorye for the first time. According to Scarlato (1981), it has been known in the Sea of Japan only within Peter the Great Bay, Chikhacheva (De-Kastri) Bay and along the western coast of Sakhalin Island.

M. e. More than $100 \mathrm{~s}$.

Subfamily Modiolinae Keen, 1958

Modiolus (Modiolus) kurilensis Bernard, 1983

Records. Vrangel Bay: sta. 31. 
Occurrence. One empty shell was taken in $7 \mathrm{~m}$.

Remarks. We do not support the viewpoint of Coan \& Scott (1997) that M. kurilensis is a synonym of Modiolus modiolus (L., 1758).

M. e. 1 s.

Superfamily Glycymeridoidea Newton, 1922

Family Glycymerididae Newton, 1922

Subfamily Glycymeridinae Newton, 1922

Glycymeris (Glycymeris) yessoensis (Sowerby, 1889)

Records.Vrangel Bay: sta. 32.

Occurrence. One empty shell was taken in $9 \mathrm{~m}$, among small pebbles.

M. e. 1 s.

Superfamily Arcoidea Lamarck, 1809

Family Arcidae Lamarck, 1809

Subfamily Arcinae Lamarck, 1809

Arca boucardi Jousseaume, 1894

Records. Vrangel Bay: sta. 5; middle Primorye: sta. 36, 41, 42.

Occurrence. Empty shells were taken in Vrangel Bay in $11 \mathrm{~m}$, in mud with sand admixture. In middle Primorye it was found in Sokolovskaya and Dzhigit Bays, and near Cape Titova, in total bathymetric range of $10-18 \mathrm{~m}$, on rocky bottom.

Remarks. This species has been known from Peter the Great Bay in Russian waters of the Sea of Japan (Scarlato, 1981). Dzhigit Bay $\left(44^{\circ} 46^{\prime}\right.$ ) is the northernmost locality of $A$. boucardi on the continental coast of the sea. We also established that this species occurs on the coast of Kunashir Island, the southern Kuril Islands (based on the collection of the ZMFU - Darkina and Lutaenko, 1996). The findings of $A$. boucardi in Busse Lagoon (southern Sakhalin, Okhotsk Sea) (Evseev, 1981) and in coastal waters of Moneron Island (Romeyko \& Kamenev, 1985) extend its distributional range northward. These new records make it possible to change the zonal-geographical characteristics of the species from subtropical (Scarlato, 1981) to subtropical-lowboreal (Fig. 6).

M. e. $8 \mathrm{~s}$.

Superfamily Anomioidea Rafinesque, 1815

Family Anomiidae Rafinesque, 1815

Subfamily Placunanomiinae Beu, 1967

Pododesmus macrochisma (Deshayes, 1839)

Records. Middle Primorye: sta. 29, 34, 40-42.

Occurrence. This species is very common to the middle Primorye area and was found in Sokolovskaya, Rudnaya, Plastun Bays, and near Cape Titova on rocky bottom. Empty shells were taken at a depth range of $9-15 \mathrm{~m}$, live specimens - in $10-32 \mathrm{~m}$. Fedorov (1991) found this species along the coast of Primorye at a depth range $25-70 \mathrm{~m}$.

M. e. 20 s. 


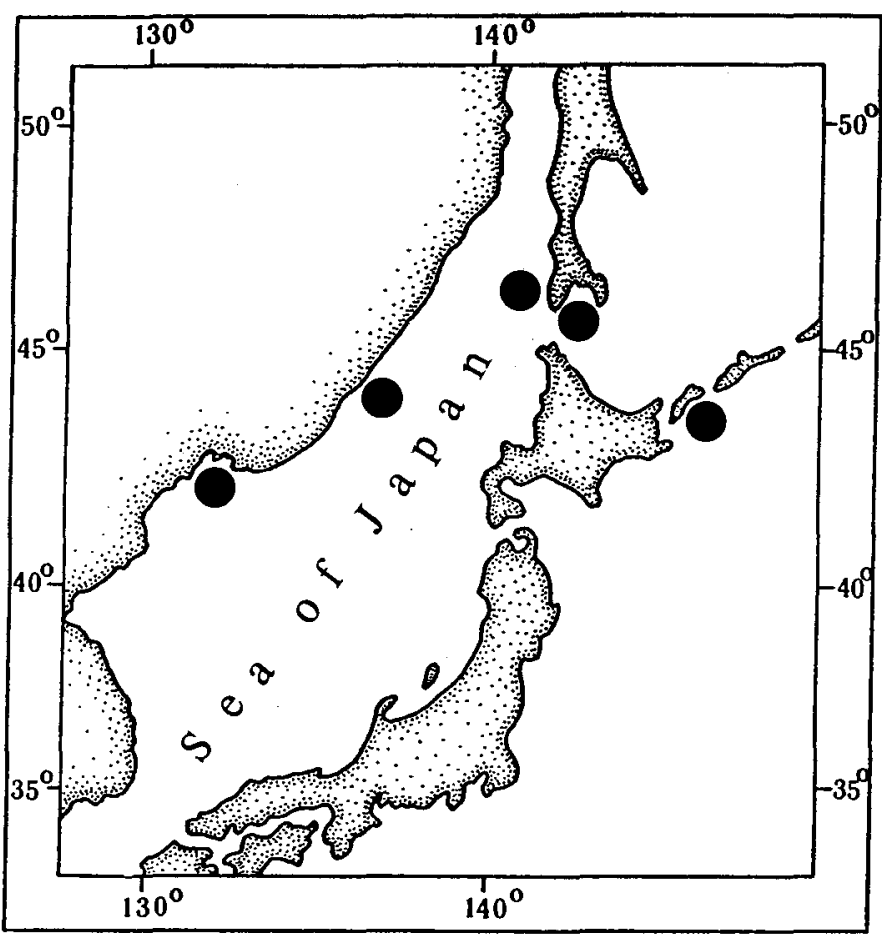

Fig. 6. Distribution of Arca boucardi Jousseaume (Arcidae) in the Russian Far Eastern regions.

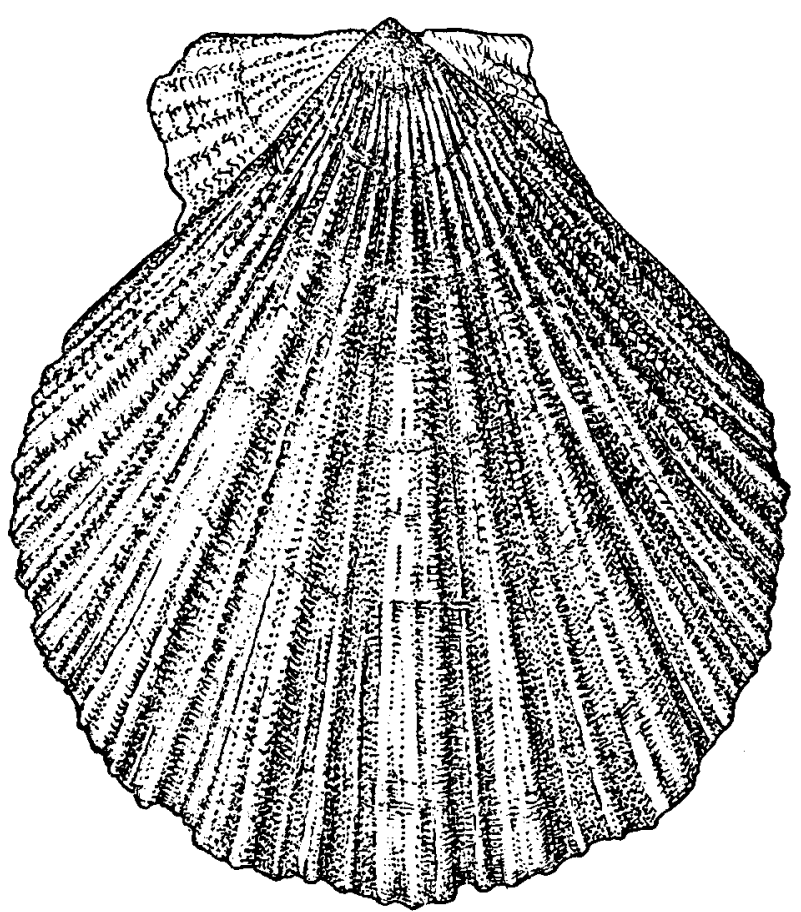

Fig. 7. Chlamys (Chlamys) albida (Dall) (Pectinidae): middle Primorye, sta. 39, depth $111 \mathrm{~m}$. Left valve, height $38 \mathrm{~mm}$. MIMB. 
Subfamily Ostreinae Rafinesque, 1815

Crassostrea gigas (Thunberg, 1783)

Records. Vrangel Bay: sta. 4-5, 10, 14, 20, 22, 23.

Occurrence. Only empty shells and shell fragments of this species were taken in 4 $25 \mathrm{~m}$, in mud and sand.

M. e. 13 s.

Superfamily Pectinoidea Wilkes, 1810

Family Pectinidae Wilkes, 1810

Subfamily Chlamydinae von Teppner, 1922

Chlamys (Chlamys) albida (Dall, 1906)

Fig. 7

Records. Middle Primorye: sta. 39.

Occurrence. Empty shell was taken in $111 \mathrm{~m}$, in muddy sand with pebbles.

Remarks. This species was earlier registered only in the northern part of the Sea of Japan (Tatarsky (Mamiya) Strait) (Scarlato, 1981).

M. e. 1 s.

\section{Chlamys (Chlamys) cf. behringiana (Middendorf, 1849) \\ Plate I, figs. 1-3}

Records. Middle Primorye: sta. 39.

Occurrence. Empty shells were taken in $111 \mathrm{~m}$, in muddy sand with pebbles.

Remarks. Kafanov (1991) stated that Pecten (Chlamys) hericeus var. strategus Dall, 1898 regarded by Scarlato $(1960,1981)$ and Habe (1977) as a distinct species, Ch. stratega, is a synonym of Ch. behringiana. According to Scarlato (1981), Ch. stratega inhabits the continental coast of the Sea of Japan, but Ch. behringiana has not been recorded in the sea except for unchecked record in the catalogue of mollusks of the ZMFU (Darkina and Lutaenko, 1996) and doubtful record of a new subspecies Chlamys behringiana scarlatovi Myasnikov, Zgurovsky et Temnych, 1992 (Myasnikov et al., 1992) for which holotype was not fixed and location of syntypes are unknown. Our identification needs further verification.

M. e. $5 \mathrm{~s}$.

Chlamys (Chlamys) chosenica Kuroda, 1932

Plate I, fig. 5

Records. Middle Primorye: sta. 39.

Occurrence. Both live specimens and empty shells were taken in $111 \mathrm{~m}$, in muddy sand with pebbles.

M. e. 42 s.

Chlamys (Szwiftopecten) swifti (Bernardi, 1858)

Records. Middle Primorye: sta. 27, 29, 34-37, 41, 42.

Occurrence. This species was collected in Sokolovskaya, Oprichnik, Plastun, Dzhigit, Udobnaya Bays, and near Capes Tumannyi and Titova in total bathymetric range of a $0.5-20 \mathrm{~m}$, on rocky bottom. 
M. e. 37 s.

Subfamily Propeamussiinae Abbot, 1954

\section{Parvamussium (Polynemamussium) alaskense (Dall, 1871)}

Records. Middle Primorye: sta. 39.

Occurrence. Live specimens were taken in $111 \mathrm{~m}$, in muddy sand with pebbles. M. e. 4 s.

Subfamily Fortipectininae Masuda, 1963

Mizuhopecten yessoensis (Jay, 1857)

Records. Vrangel Bay: sta. 10; middle Primorye: sta. 33.

Occurrence. Empty shells were taken in subtidal zone of Kitovoe Rebro Bay, and in Vrangel Bay in $17.5 \mathrm{~m}$.

Remarks. According to Scarlato (1981), this species extends along the continental coast of the Sea of Japan as far north as Rudnaya Bay, although it occurs also in Chikhacheva (De-Kastri Bay), the northernmost locality in the sea. Kitovoe Rebro Bay is a new northern locality of the species.

M. e. 2 s.

Subclass Heterodonta

Superfamily Lucinoidea Fleming, 1828

Family Ungulinidae H. Adams et A. Adams, 1857

\section{Felaniella usta (Gould, 1861)}

Records. Vrangel Bay: sta. 5, 14, 17, 21, 32; middle Primorye: sta. 41.

Occurrence. Empty shells were taken in Vrangel Bay in $3.5-11 \mathrm{~m}$ in sandy mud, sand and pebbles, and near Cape Titova in $15 \mathrm{~m}$, on rocky bottom.

M. e. $40 \mathrm{~s}$.

Family Thyasiridae Dall, 1901

Axinopsida subquadrata (Adams, 1862)

Records. Vrangel Bay: sta. 1, 3, 6, 8, 10, 16, 18, 24, 25, 30, 33; middle Primorye: sta. 29.

Occurrence. This species is very common in Vrangel Bay and was collected there at a depth range of $4-25 \mathrm{~m}$, in mud, sand and muddy sand; in middle Primorye one empty shell was taken in Oprichnik Bay, in $17 \mathrm{~m}$, in muddy sand.

M. e. $23 \mathrm{~s}$.

Superfamily Galeommatoidea Gray, 1840

Family Lasaeidae Gray, 1847

Kellia japonica Pilsbry, 1895

Records. Middle Primorye: sta. 34, 36, 37, 41.

Occurrence. This species was taken in Plastun, Dzhigit, Udobnaya Bays, and near Cape Titova in $1-15 \mathrm{~m}$, on rocky bottom.

M. e. $8 \mathrm{~s}$. 
Family Montacutidae Clark, 1855

\section{Mysella (?) sp.}

Records. Middle Primorye: sta. 41.

Occurrence. One empty shell was taken near Cape Titova, in $15 \mathrm{~m}$.

M. e. 1 s.

Superfamily Carditoidea Fleming, 1828

Family Carditidae Fleming, 1828

Subfamily Venericardiinae Chavan, 1969

\section{Cyclocardia (Crassicardia) crassidens (Broderip et Sowerby, 1829)}

Records. Middle Primorye: sta. 40, 42.

Occurrence. Live specimens were taken in Sokolovskaya and Rudnaya Bays, in 32 -.. $50 \mathrm{~m}$, on rocky bottom.

Remarks. We follow Coan \& Scott (1997) regarding Crassicardia Savizky, 1979 as only a subgenus.

M. e. 7 s.

Superfamily Cardioidea Lamarck, 1809

Family Cardiidae Lamarck, 1809

Subfamily Laevicardiinae Keen, 1936

\section{Clinocardium (Keenocardium) californiense (Deshayes, 1839)}

Plate II, fig. 4

Records. Vrangel Bay: sta. 5, 14, 17, 18, 23-25, 29, 31, 33; middle Primorye: sta. 29, 37,41 .

Occurrence. In Vrangel Bay, empty shells were taken in $4-12.5 \mathrm{~m}$, in muddy sand, pebbles and sand; live specimens were collected in $7-12.5 \mathrm{~m}$, in muddy sand and sand. Empty shells were found in middle Primorye at a depth range of $3-15 \mathrm{~m}$, in Oprichnik and Udobnaya Bays, and near Cape Titova, on rocky bottom. One live specimen was collected near Cape Titova in $30 \mathrm{~m}$, in sand.

M. e. 17 s.

\section{Clinocardium (Ciliatocardium) ciliatum (Fabricius, 1780)}

Records. Middle Primorye: sta. 39.

Occurrence. One empty shell was taken in $111 \mathrm{~m}$, in muddy sand with pebbles.

Remarks. This widely distributed boreal-arctic species occurring both the Atlantic and Pacific Oceans was subdivided by Kafanov (1981) into six morphological groups formally designated as subspecies. One of the subspecies described by Kafanov (in Scarlato, 1981), inhabits the Sea of Japan (Clinocardium(Ciliatocardium) ciliatum tchuktchense (Kafanov in Scarlato, 1981)) in its northern part, southern Primorye and the coast of Hokkaido. Middle Primorye is a new locality of this species except for records from the Holocene deposits (Evseev, 1981).

M. e. 1 s.

Clinocardium (Giliatocardium) likharevi Kafanov in Scarlato, 1981 
Records. Middle Primorye: sta. 39.

Occurrence. One live specimen was taken in $111 \mathrm{~m}$, in muddy sand with pebbles.

Remarks. This doubtful species might be a synonym of $C$. ciliatum. This is the first record for the middle Primorye area.

M. e. 1 s.

Subfamily Serripedinae Kafanov, 1975

\section{Serripes groenlandicus (Mohr, 1786)}

Plate II, figs. 5

Records. Vrangel Bay: sta. 6, 13, 17; middle Primorye: sta.39.

Occurrence. In Vrangel Bay, empty shells were taken at a depth range of $4.5-25$ $\mathrm{m}$, in sandy mud and sand; in middle Primorye; empty shells were found in $111 \mathrm{~m}$, in muddy sand with pebbles.

Remarks. According to Scarlato. (1981), this species has been known in the Sea of Japan only from the bathymetric range of $14-65 \mathrm{~m}$. See about authorship of this species: Coan \& Scott, 1997.

M. e. $6 \mathrm{~s}$.

Superfamily Mactroidea Lamarck, 1809

Family Mactridae Lamarck, 1809

Subfamily Mactrinae Lamarck, 1809

\section{Mactra (Mactra) chinensis Philippi, 1846}

Records. Middle Primorye: sta. 27.

Occurrence. Live specimens were found near Cape Tumannyi in $9-12 \mathrm{~m}$, in sand.

Remarks. Cape 'Tumannyi is the northernmost locality of this species on the continental coast of the Sea of Japan; according to Scarlato (1981), M. chinensis has been known as far north as Sokolovskaya Bay.

M. e. 1 s.

\section{Spisula (Pseudocardium) sachalinensis (Schrenck, 1862)}

Records. Middle Primorye: Dzhigit Bay (between sta. 35 and sta. 36).

Occurrence. Empty shells were collected as beach drift.

Remarks. Dzhigit Bay is a new northern locality of $S$. sachalinensis; according to Scarlato (1981), this species has been known as far north as Olga Bay.

M. e. 2 s.

Subfamily Pteropsellinae Keen, 1969

\section{Raeta (Raetellops) pulchella (Adams et Reeve, 1850)}

Records. Vrangel Bay: sta. 6, 10, 13, 17, 19, 24, 30, 33.

Occurrence. This species was taken in total bathymetric range of $4.5-25 \mathrm{~m}$, in mud, sand and muddy sand.

M. e. $14 \mathrm{~s}$. 
Records. Middle Primorye: sta. 33, 34.

Occurrence. Live specimens were taken in Kitovoe Rebro and Plastun Bays, in $6 \mathrm{~m}$, in coarse-grained sand.

Remarks. This species has been as far north as Vladimir Bay (Scarlato, 1981). Plastun Bay is a new northernmost locality on the continental coast of the Sea of Japan.

M. e. $8 \mathrm{~s}$.

Subfamily Macominae Olsson, 1961

Macoma (Macoma) calcarea (Gmelin, 1791)

Records. Middle Primorye: sta. 39. pebbles.

Occurrence. Empty (?subfossil) shells were taken in $111 \mathrm{~m}$, in muddy sand with

M. e. $33 \mathrm{~s}$.

\section{Macoma (Macoma) incongrua (Martens, 1865)}

Records. Vrangel Bay: sta. 17.

Occurrence. One empty shell was taken in $11.5 \mathrm{~m}$, in muddy sand.

M. e. $1 \mathrm{~s}$.

\section{Macoma (Macoma) scarlatoi Kafanov et Lutaenko, 1997}

Plate II, fig. 8

Records. Vrangel Bay: sta. 1, 3, 6, 10, 13, 22, 24, 25.

Occurrence. Live specimens were taken in total bathymetric range of $7-25 \mathrm{~m}$, in mud, muddy sand and sand; empty shells were collected in $4.5-17.5 \mathrm{~m}$.

Remarks. M. scarlatoi is nom. nov. pro Macoma orientalis Scarlato in Golikov et Scarlato, 1967 non Macoma (Cymatoica) orientalis (Dall, 1890) (see Kafanov and Lutaenko, 1997).

M. e. 16 s.

\section{Macoma (Macoma) golikovi Scarlato et Kafanov, 1988}

Plate II, fig. 11

Records. Vrangel Bay: sta. 5.

Occurrence. Empty shell (one valve) was found in $11 \mathrm{~m}$, in muddy sand.

Remarks. This species was originally described by Scarlato (1981) as Macoma orbiculata Scarlato, 1981 from southern Sakhalin Island (both Japan and Okhotsk Seas sides). Due to preoccupation, Scarlato and Kafanov (1988) proposed a new name, M. golikovi nom. nov. pro Macoma orbiculata Scarlato, 1981 non Kanno, 1958. We suppose that Macoma lukini Kamenev, 1990 known from the Kuril and Commander Islands, Avacha Bay (Kamchatka) and Tauiskaya Inlet (Okhotsk Sea) in the Russian Far East seas, is a synonym of M. golikovi (see figures in Scarlato, 1981 and Kamenev, 1990, 1995). Evseev (1981) certainly mentioned M. golikovi under the heading Macoma arnheimi Dall (p. 134, pl. I, figs. 1, 4). M. arnheimi was discovered in the Holocene deposits of Cape Povorotny (eastern part of Peter the Great Bay) and along Primorye coast as far north as Zerkalnaya Bay. Probably, M. golikovi became extinct along the continental coast of the Sea of Japan during the mid-Holocene warming, 
but it still exists in high-boreal regions of the western Pacific Ocean. Amano (1996) also suggested that Macoma orbiculata Scarlato migrated to the Sea of Japan only after the Late Pleistocene. On the other hand, M. lukini, M. golikovi and M. arnheimi of Evseev (1981) are similar in general features to Macoma obliqua (Sowerby, 1817) from the eastern Pacific (see also: Kamenev, 1995, p. 10) originally described from the Pleistocenedeposits of Europe (Coan, 1971). Kamenev (1995) regarded M. lukini as a Pacific amphiboreal species occuring off the shores of both Asia and North America, but he did not discuss the relationships between $M$. golikori (= M. orbiculata Scarlato, 1981) and M. lukini.

M. e. 1 s.

\section{Macoma (Macoma) middendorffi Dall, 1884}

Plate I, fig. 4; plate II, fig. 1

Records. Vrangel Bay: sta. 31; middle Primorye: sta. 39.

Occurrence. Empty shells were taken in Vrangel Bay in $7 \mathrm{~m}$, in gravel and sand, and in middle Primorye in $111 \mathrm{~m}$, in muddy sand with pebbles.

Remarks. This species has been known in Primorye only from Olga Bay (Scarlato, 1981). According to Evseev (1981), it is also found in the Holocene deposits of Vostok Bay and along the coast of Primorye as far north as Zerkalnaya Bay at a depth range of approximately $10-60 \mathrm{~m}$. We established that $M$. middendorffi occurs on the coast of Peter the Great Bay - Boysman Bay and Popov Island (beach drift; collection of the ZMFU).

M. e. 2 s.

Family Semelidae Stoliczka, 1870

\section{Theora fragilis A. Adams, 1855}

Records. Vrangel Bay: sta. 6, 8, 10, 13, 17, 24, 25, 28, 33.

Occurrence. Living specimens are very abundant in Vrangel Bay and were taken at a bathymetric range of $4.5-25 \mathrm{~m}$, in mud and muddy sand, sometimes in finely grained sand.

M. e. $79 \mathrm{~s}$.

Family Psammobiidae Flemming, 1828

Subfamily Sanguinolariinae Grant et Gale, 1931

Nuttallia ezonis Kuroda et Habe, 1955

Plate II, fig. 6

Records. Vrangel Bay: sta. 14, 18, 23.

Occurrence. Empty shells were taken in $4-7.5 \mathrm{~m}$, in sand.

M. e. $4 \mathrm{~s}$.

Superfamily Solenoidea Lamarck, 1809

Family Gultellidae Davies, 1935

\section{Siliqua alta (Broderip et Sowerby, 1829)}

Records. Vrangel Bay: sta. 14.

Occurrence. Empty shell was found in $7.5 \mathrm{~m}$, on rocky (?) bottom.

M. e. $1 \mathrm{~s}$. 
Superfamily Veneroidea Rafinesque, 1815

Family Veneridae Rafinesque, 1815

Subfamily Chioninae Frizzel, 1936

Mercenaria stimpsoni (Gould, 1861)

Records. Vrangel Bay: sta. 14, 21, 23, 31, 32; middle Primorye: sta. 36.

Occurrence. Empty shells of this species were taken in Vrangel Bay at total bathymetric range of $4-9 \mathrm{~m}$, in sand and pebbles; one live specimen was found in Dzhigit Bay, in 9 $\mathrm{m}$, ins and among sea-grass Zostera.

Remarks. Dzhigit Bay is a new northern locality of $M$. stimpsoni on the continental coast of the Sea of Japan. This species has been known as far north as Vladimir Bay (Scarlato, 1981).

M. e. $8 \mathrm{~s}$.

\section{Callithaca adamsi (Reeve, 1863)}

Records. Vrangel Bay: sta. 2, 4, 10,'18, 20, 23, 24.

Occurrence. Live specimens were found in $4-12.7 \mathrm{~m}$, mainly in sand, or muddy sand; empty shells were taken in $4-17.5 \mathrm{~m}$, in mud and sand.

M. e. $10 \mathrm{~s}$.

\section{Protothaca (Notochione) jedoensis (Lischke, 1874)}

Records. Vrangel Bay: sta. 31; middle Primorye: sta. 29.

Occurrence. Empty shells were taken in Vrangel Bay in $7 \mathrm{~m}$, among pebbles and sand, and in Oprichnik Bay in 3-4 $\mathrm{m}$, among boulders.

Remarks. Oprichnik Bay $\left(44^{\circ} 26^{\prime} \mathrm{N}\right)$ is a new northern locality of this species on the continental coast of the Sea of Japan. According to Scarlato (1981), P. jedoensis has been known only up to $42^{\circ} 50^{\prime} \mathrm{N}$ along the coast of Primorye.

M. e. $2 \mathrm{~s}$.

\section{Protothaca (Novathaca) euglypta (Sowerby, 1914)}

Records. Vrangel Bay: sta. 18; middle Primorye: sta. 27, 29, 36, 37.

Occurrence. Alive mollusks were found in Oprichnik, Dzhigit and Udobnaya Bays, and near Cape Tumannyi, at a total bathymetric range of $4-18 \mathrm{~m}$, in sand, among sea-grass Phyllospadix, and on the rocky bottom covered with sponges. Empty shells were taken in Vrangel Bay in $4 \mathrm{~m}$, in sand, and in Oprichnik Bay in $3-4 \mathrm{~m}$, among boulders.

Remarks. Udobnaya Bay is a new northern locality of $P$. euglypta on the coast of Primorye; it has been known as far north as Olga Bay (Scarlato, 1981).

M. e. 32 s.

Subfamily Tapetinae H. Adams et A. Adams, 1857

Ruditapes philippinarum (Adams et Reeve, 1850)

Records. Vrangel Bay: sta. 13, 20, 23.

Occurrence. Empty shells were taken in $4-6 \mathrm{~m}$, in sand; one live specimen was found in $4.5 \mathrm{~m}$.

M. e. 5 s. 


\section{Liocyma fluctuosa (Gould, 1841) s.1. \\ Plate II, fig. 3}

Records. Vrangel Bay: sta. 4, 5, 13, 14, 17, 20, 23; middle Primorye: sta. 28.

Occurrence. Empty shells were taken in Vrangel Bay in $4-16.5 \mathrm{~m}$, in sand and mud. Live specimens were found near Cape Tummanyi in $47 \mathrm{~m}$, in muddy sand.

M. e. $20 \mathrm{~s}$.

Subfamily Callistinae Nordsieck, 1969

\section{Callista (Ezocallista) brevisiphonata Carpenter, 1865}

Records. Vrangel Bay: sta. 32; middle Primorye: sta. 29, 33.

Occurrence. Empty shells were taken in Vrangel Bay in $9 \mathrm{~m}$, among pebbles, and in Kitovoe Rebro Bay. Live specimens were found in Oprichnik Bay in $12 \mathrm{~m}$, in sand.

Remarks. Kitovoe Rebro Bay is a new northern locality of $C$. brevisiphonata known previously as far north as Olga and Vladimir Bays along the coast of Primorye (Scarlato, 1981). Callista trigonoovata Scarlato in Volova et Scarlato, 1980 described from Peter the Great Bay (Volova and Scarlato, 1980) appears to be a synonym of $C$. brevisiphonata (Kafanov and Lutaenko, in press).

M. e. $6 \mathrm{~s}$.

Superfamily Myoidea Lamarck, 1809

Family Myidae Lamarck, 1809

Subfamily Myinae Lamarck, 1809

Mya (Mya) truncata L., 1758

Plate I, fig. 6

Records. Vrangel Bay: sta. 19.

Occurrence. One live specimen was taken in $11.5 \mathrm{~m}$, in fine-grained sand.

M. e. 1 s.

\section{Mya (Mya) uzenensis Nomura et Zinbo, 1937}

Records. Vrangel Bay: sta. 18, 32.

Occurrence. Empty shells were taken in $4-9 \mathrm{~m}$, in sand and pebbles.

Remarks. This species has been known for a long time as Mya priapus Tilesius, 1822. We follow Scarlato \& Kafanov (1988) and other authors that priapus is most likely Panomya (family Hiatellidae); Coan \& Scott (1997) suggested that $M$. uzenensis described from the Miocene of Japan might be a synonym of Mya pseudoarenaria Schlesch, 1931.

M. e. 2 s.

\section{Mya (Arenomya) japonica Jay, 1857}

Records. Vrangel Bay: sta. 10, 13, 14, 20, 25.

Occurrence. Empty shells were taken in $4.5-17.5 \mathrm{~m}$, in mud and sand.

M. e. 6 s.

Subfamily Cryptomyinae Habe, 1977

Cryptomya busoensis Yokoyama, 1922

Records. Middle Primorye: sta. 36. 
Occurrence. Empty shell was found in Dzhigit Bay in $18 \mathrm{~m}$, on rocky bottom.

Remarks. This is the first record of $C$. busoensis in middle Primorye. According to Scarlato (1981), this species has been known only from Possjet Bay (south-western part of Peter the Great Bay). Evseev (1981) recorded C. busoensis from the Holocene deposits of Primorye.

M. e. $1 \mathrm{~s}$.

Family Corbulidae Lamarck, 1818

Subfamily Corbulinae Lamarck, 1818

Anisocorbula venusta (Gould, 1861)

Records. Middle Primorye: sta. 27, 29, 35, 36, 41.

Occurrence. Live mollusks were taken in Oprichnik, Plastun, and Dzhigit Bays, and near Cape Tumannyi at total bathymetric range of $0.5-18 \mathrm{~m}$, on rocky bottom and in sand covered by sea-grass Phyllospadix.

Remarks. Dzhigit Bay is a new northern locality of $A$. venusta in Primorye. According to Scarlato (1981), it has been known as far north as Olga Bay.

M. e. $10 \mathrm{~s}$.

Superfamily Hiatelloidea Gray, 1824

Family Hiatellidae Gray, 1824

Hiatella arctica (L., 1767)

Records. Middle Primorye: sta. 36, 37, 39-41.

Occurrence. Empty shells were taken in Rudnaya, Dzhigit, and Udobnaya Bays, and near Cape Titova at total bathymetric range of 2-32 $\mathrm{m}$, on rocky bottom. Live mollusks were found in Udobnaya Bay in $2 \mathrm{~m}$, and in $111 \mathrm{~m}$ (sta. 39), in muddy sand with pebbles.

M. e. 27 s.

\section{Panomya norvegica (Spengler, 1793)}

Plate II, fig. 2

Records. Vrangel Bay: sta. 14; middle Primorye: sta. 41.

Occurrence. Empty shells were taken in Vrangel Bay in $7.5 \mathrm{~m}$, and near Cape Titova, in $15 \mathrm{~m}$, on rocky bottom.

Remarks. $P$. norvegica is recorded in middle Primorye for the first time. Evseev's (1981) Panomya ampla Dall from the Holocene deposits of Primorye is most likely $P$. norvegica or $P$. nipponica Nomura et Hatai, 1935.

M.e. 2 s.

Subclass Anomalodesmacea Superfamily Pandoroidea Rafinesque, 1815

Family Lyonsiidae Fischer, 1887

\section{Agriodesma navicula (Adans et Reeve, 1850)}

Records. Middle Primorye: sta. 41, 42.

Occurrence. Live mollusks were taken in Sokolovskaya Bay, and near Cape Titova in $2-15 \mathrm{~m}$, on rocky bottom, among sea-grass bed Phyllospadix.

M. e. 2 s. 
Family Pandoridae Rafinesque, 1815

Pandora (Heteroclidus) pulchella Yokoyama, 1926

Plate II, figs. 7, 10

Records. Vrangel Bay: sta. 17.

Occurrence. Live specimen was taken in $11.5 \mathrm{~m}$, in sandy mud.

M. e. 1 s.

Pandora (Heteroclidus) zeardiana A. Adams, 1859

Records. Middle Primorye: sta. 39.

Occurrence. Live mollusks were taken in $111 \mathrm{~m}$, in muddy sand with pebbles.

M. e. 2, specimens.

Family Thraciidae Stoliczka, 1870

Thracia itoi Habe, 1961

Plate II, fig. 9

Records. Vrangel Bay: sta. 31.

Occurrence. Empty shells were taken in $7 \mathrm{~m}$, among pebbles with sand.

M. e. 2 s.

\section{DISCUSSION}

A total of 58 species of bivalves were identified from the two areas studied in the Primorye Territory, continental coast of the Sea of Japan (Table 2). Thirty-six and 37 species were found in Vrangel Bay and along the coast of middle Primorye, respectively. Cadella lubrica (Gould, 1861) (Tellinidae) can be added to the list of mollusks of Nakhodka Bay based on the examination of collections of the ZMFU (Darkina \& Lutaenko, 1996). In comparison, over 130 bivalve species inhabit entire Peter the Great Bay, and over 110 species are known from the Northern Primorye District (Scarlato, 1981) which includes the coast of Primorye north of Cape Povorotny (the eastern boundary of Peter the Great Bay), the Tatarsky (Mamiya) Strait and the coast of north-western Sakhalin. The total number of bivalves in Primorye is still unknown. Romeyko (1985) mentioned 114 species and subspecies of bivalves from the northern part of the Sea of Japan, but she did not present a precise species list.

In Vrangel Bay, samples containing mollusks were taken from soft bottoms, while samples from middle Primorye were taken mainly on rocky bottoms by the SGUBA-diving method. Thus, molluscan lists for both areas are impoverished due to different sampling techniques. Nevertheless, we have undertaken an attempt to consider some ecological, faunal, and biogeographical peculiarities of these areas based on the molluscan data obtained.

The most common species of bottom molluscan communities in Vrangel Bay are Macoma scarlatoi Kafanov et Lutaenko, 1997, Axinopsida subquadrata (Adams, 1862), Clinocardium californiense (Deshayes, 1839), Raeta pulchella (Adams et Reeve, 1848), Callithaca adamsi (Reeve, 1863), Liocyma fluctuosa (Gould, 1841), and Theora fragilis A. Adams, 1855. Some of these were chiefly represented by empty shells ( $M$. scarlatoi, $C$. adamsi, etc.), but the presence of live specimens indicates wide distribution of these species in the bay. The most abundant bivalve was the small semelid Th. fragilis. It was found in the bathymetric range of $4.5-25 \mathrm{~m}$ at nine stations, commonly in large numbers. Th. fragilis 
serves as an indicator of organic pollution in some coastal areas of Korea (Hong et al., 1994; Lim et al., 1995) and Japan (Yokoyama et al., 1996). For example, in Chinhae Bay (the southern coast of Korea) the population density of this species appeared to be related to the sediment organic carbon content and increased with the organic content of sediments (Lim et al., 1995). In Gokasho Bay (the Pacific coast of Japan), Th. fragilis expanded its range from the innermost part to the central part of the bay due to eutrophication when compared to a previous survey conducted in 1941 (Yokoyama et al., 1996). The coastal area of Vrangel Bay is occupied by Port Vostochny, the largest Russian Far East commercial port and industrial complex. This probably leads to a rapid modification of benthic communities of Vrangel Bay over the past few decades and changes in abundance and local distributions of several molluscan species as illustrated by $T$. fragilis.

Another important ecological and faunal feature of Vrangel Bay are cold-water and relatively cold-water mollusks occurring in shallow water. For instance, L. fluctuosa, Serripes groenlandicus (Mohr, 1786), Panomya norvegica (Spengler, 1793), and Mya truncata L., 1758 are typical boreal-arctic species commonly found in mid- or low-subtidal zones at temperate latidudes but in high latidudes they inhabit upper-subtidal or even intertidal zones. This phenomenon called submergence (occurence of cold-water species at greater depths in the low-latitude margin of their range) is quite common in temperate latitudes (Dodd \& Stanton, 1981) and can be illustrated for the species mentioned above. According to Klimova (1974, 1975) and Scarlato (1981), L. fuctuosa occurs in the north-western part of the Sea of Japan at depths greater than $30-50 \mathrm{~m}$, and $S$. groenlandicus is generally found in Peter the Great Bay at a depth of 50-60 m. P. norvegica was recorded in Far Eastern seas at depths below 30 $\mathrm{m}$; Scarlato (1981) also mentioned finding this species (young specimens) at $10-12 \mathrm{~m}$ in Peter the Great Bay but these records, in fact, refer to an allied species, Panomya nipponica Nomura et Hatai, 1935. In order to find the pattern of bathymetric distribution of mollusks collected in our study, we compiled data on their depth ranges in different parts of Russian, Korean and Japanese sides of the Sea of Japan, based upon available literature sources (Tables 3, 4). The results of comparison will be discussed further.

Thus, Vrangel Bay is characterized by relatively cold-water conditions reflected in the faunal composition of mollusks. This is quite surprising since many warm-water species of the subtropical or even tropical nature commonly inhabit semi-enclosed bays and head parts of large embayments in Peter the Great Bay. Golikov \& Scarlato (1967) and Scarlato (1981) have shown that this phenomenon can be explained by the intense summer warming which is necessary for successful reproduction of warm-water species, and results in the formation of stable groups with nearly annual reproduction. Winter cooling in itself does not prevent subtropical fauna from living in temperate latitudes (see Scarlato, 1981). An additional reason for the existence of warm-water species in semi-enclosed bays of Peter the Great Bay was the immense warming during the Middle Holocene (climatic optimum of the Holocene) that created the possibility of large-scale nearshore migrations of tropical-subtropical and subtropical mollusks to northern areas of the Sea of Japan (Lutaenko, 1991), and related changes in the current system - significant increase of warm stream activity and a northward shift of the front of the warm East Korean Current (Taira, 1995; Taira \& Lutaenko, 1993). The molluscan fauna of Vrangel Bay seems to be the exception from the general rule of concentration of warm-water species in semi-enclosed bays of Peter the Great Bay. Japanese malacologists (cited after Scarlato, 1981) found that along the Pacific coast of Japan the molluscan fauna of bays comprises cold-water elements and can be regarded as more cold-water when compared to the fauna of the open coast. 'This is due to the warm Kuroshio Current creating suitable conditions for subtropical species in open areas and not influencing the hydrological regime inside the bays. In the case 
Table 2. Species list of bivalve mollusks found in Vrangel Bay and along the middle Primorye coast.

\begin{tabular}{|c|c|c|}
\hline Species & Vrangel Bay & Middle Primorye \\
\hline 1. Nucula ovatotruncata & + & \\
\hline 2. Acila insignis & + & \\
\hline 3. Nuculana sadoensis & & + \\
\hline 4. Yoldia johanni & + & + \\
\hline 5. Yoldia notabilis & + & \\
\hline 6. Vilasina pillula & & + \\
\hline 7. Crenomytilus grayanus & + & + \\
\hline 8. Mytilus edulis & + & \\
\hline 9. Modiolus kurilensis & + & \\
\hline 10. Glycymeris yessoensis & + & \\
\hline 11. Arca boucardi & + & + \\
\hline 12. Crassostrea gigas & + & \\
\hline 13. Pododesmus macrochisma & & + \\
\hline 14. Chlamys albida & & + \\
\hline 15. Chlamys cf. behringiana & & + \\
\hline 16. Chlamys chosenica & & + \\
\hline 17. Chlamys swifti & & + \\
\hline 18. Parvamussium alaskense & & + \\
\hline 19. Mizuhopecten yessoensis & + & + \\
\hline 20. Felaniella usta & + & + \\
\hline 21. Axinopsida subquadrata & + & + \\
\hline 22. Kellia japonica & & + \\
\hline 23. Mysella (?) sp. & & + \\
\hline 24. Cyclocardia crassidens & & + \\
\hline 25. Clinocardium californiense & + & + \\
\hline 26. Clinocardium ciliatum & & + \\
\hline 27. Clinocardium likharevi & & + \\
\hline 28. Serripes groenlandicus & + & + \\
\hline 29. Maclra chinensis & & + \\
\hline 30. Spisula sachalinensis & & + \\
\hline 31. Raeta pulchella & + & \\
\hline 32. Cadella lubrica & & + \\
\hline 33. Macoma calcarea & & + \\
\hline 34. Macoma incongrua & + & \\
\hline 35. Macoma scarlatoi & + & \\
\hline 36. Macoma golikovi & + & \\
\hline 37. Macoma middendorffi & + & + \\
\hline 38. Nuttallia ezonis & + & \\
\hline 39. Theora fragilis & + & \\
\hline 40. Siliqua alta & + & \\
\hline 41. Mercenaria stimpsoni & + & + \\
\hline 42. Callithaca adamsi & + & \\
\hline 43. Prothotaca jedoensis & + & + \\
\hline 44. Prothotaca euglypta & + & + \\
\hline 45. Ruditapes philippinarum & + & \\
\hline 46. Liocyma fluctuosa & + & + \\
\hline 47. Callista brevisiphonata & + & + \\
\hline 48. Mya truncata & + & \\
\hline
\end{tabular}


Table 2. (Continued)

\begin{tabular}{llcc}
\multicolumn{1}{c}{ Species } & Vrangel Bay & Middle Primorye \\
\hline 49. Mya uzenensis & + & \\
50. Mya japonica & + & + \\
51. Cryptomya busoensis & & + \\
52. Anisocorbula venusta & + & + \\
53. Hiatella arctica & + & + \\
54. Panomya norvegica & + & + \\
55. Agriodesma navicula & + & + \\
56. Pandora pulchella & & + \\
57. Pandora wardiana & Thracia itoi & & + \\
58. & & & + \\
\hline
\end{tabular}

of Vrangel Bay, the relatively cold-water character of its bivalve mollusks can be attributed to the probable influence of the cold Primorskoye Current that penetrates into the eastern, more exposed bays of Peter the Great Bay, as exemplified by Vostok and Nakhodka Bays rather than to the highly indented coast and protected western embayments, namely, Possjet, Amur and Ussuri Bays. Ivaschenko (1993) noted that the Primorskoye Current influences the eastern part of Peter the Great Bay and some open areas around islands in the Bay, but Amur and Ussuri Bays remain outside of its influence, and Stepanov (1976) observed the upwelling of deep cold water with minimum temperatures of $3-4^{\circ} \mathrm{C}$ in Vostok Bay even in August. Therefore, a combination of such features as geomorphological indentation of the coastline, local hydrological regime (intense summer warming) and the influence of currents makes it possible to recognize two types of embayments within Peter the Great Bay - semi-enclosed bays inhabited by relic mid-Holocene thermophilous molluscan fauna and those dominated by temperate and relatively cold-water (boreal-arctic in zonal-geographical terminology) fauna. In neighboring Vostok Bay, similar in hydrological conditions to Nakhodka Bay, only one extinct Holocene warm-water species, Meretrix lusoria (Roding, 1798), Veneridae (Evseev, 1976) was found, while in Possjet, Amur and Ussuri Bays, three extinct thermophilous bivalves were found - two species of the genus Anadara, Arcidae and $M$. lusoria (Lutaenko, 1993; Rakov \& Lutaenko, 1997). Other tropicalsubtropical and subtropical mollusks still existing in Peter the Great Bay as remnants of the mid-Holocene warming - Dosinia penicillata (Reeve, 1850), Mactra veneriformis Deshayes, 1853 (Mactridae), and Trapezium liratum (Reeve, 1843) (Trapeziidae) - also did not occur in either Nakhodka nor Vostok Bays. This supports the opinion that even during the climatic optimum of the Holocene $(5000-6000$ years B.P.), the warmest period of the post-glacial history, the eastern area of Peter the Great Bay was influenced by a cold current preventing the penetration of warm-water fauna into this area.

Molluscan fauna of middle Primorye, as we mentioned, is insufficiently studied. In spite of this fact, it is not surprising that a number of species (Vilasina pillula Bartsch in Scarlato, 1960, Arca boucardi Jousseaume, 1894, Chlamys albida (Dall, 1906), Ch. cf. behringiana (Middendorff, 1849), Clinocardium ciliatum (Fabricius, 1790), C. likharevi Kafanov in Scarlato, 1981, Cryptomya busoensis Yokoyama, 1922, P. norvegica) are recorded for the first time from that area. Distributional ranges of other species (Mizuhopecten yessoensis (Jay, 1857), Mactra chinensis Philippi, 1846, Spisula sachalinensis (Schrenck, 1861), C. lubrica, Mercenaria stimpsoni (Gould, 1861) should be extended northward along the coast of Primorye, although some 
Table 3. Bathymetric ranges of bivalve mollusks obtained in present study as compared to other regions of the Sea of Japan (Russian coast).

\begin{tabular}{|c|c|c|c|c|c|c|c|}
\hline Species & Are & ea $\mathrm{I}$ & Area & ea II & & Area III & In total \\
\hline 1. Nucula ovatotruncata & $3-$ & $-62[1]$ & $4.5-$ & $-\quad 17.5$ & & & $3-62$ \\
\hline 2. Acila insignis & 5 & -70 & $4-$ & $-\quad 7.5$ & & & $4-70$ \\
\hline 3. Nuculana sadoensis & 23 & $\begin{array}{l}-80 \text { and } \\
\text { eeper [2] }\end{array}$ & & 111 & & $220[2]$ & $23-220$ \\
\hline 4. Yoldia johanni & 5 & $-\quad 28$ & 4.5 & -15 & & & $4.5-\quad 28$ \\
\hline 5. Yoldia notabilis & $2-$ & $-68[3]$ & $10-$ & $-\quad 17.5$ & & & $2-68$ \\
\hline 6. Vilasina pillula & 2.5 & -21 & 0.5 & -20 & 1 & -60 & $0.5-60$ \\
\hline 7. Crenomytilus grayanus & $1-$ & -60 & 0.5 & $-\quad 12$ & 0 & -80 & $0.5-80$ \\
\hline 8. Mytilus edulis & 0 & $-\quad 10$ & 7.5 & $-\quad 25$ & 0 & -5 & $0-25$ \\
\hline 9. Modiolus kurilensis & $2-$ & $-22[4]$ & & 7 & 5 & $-80[4]$ & $2-80$ \\
\hline 10. Glycymeris yessoensis & $1.5-$ & -10 & & 9 & $?$ & -44 & $1.5-44$ \\
\hline 11. Arca boucardi & $3-$ & -10 & $10-$ & $-\quad 18$ & 7 & -80 & $3-80$ \\
\hline 12. Crassostrea gigas & $1.5-$ & -3 & 4 & $-\quad 25$ & & & $1.5-25$ \\
\hline 13. Pododesmus macroshisma & & 25 & 9 & $-\quad 32$ & 15 & -150 & $9-150$ \\
\hline 14. Chlamys albida & & & & 111 & & & 111 \\
\hline 15. Chlamys behringiana & & & & 111 & 40 & $-100[5]$ & $40-111$ \\
\hline 16. Chlamys chosenica & $13-$ & $-2030[6]$ & & 111 & 40 & $-200[6]$ & $13-2030$ \\
\hline 17. Chlamys swifii & 2 & $-46[7]$ & 0.5 & -20 & 20 & -75 & $0.5-75$ \\
\hline 18. Parvamussium alaskense & $100-$ & -350 & & 111 & 1 & -220 & $1-350$ \\
\hline 19. Mizuhopecten yessoensis & 1.5 & 80 & & 17.5 & 15 & -40 & $1.5-80$ \\
\hline 20. Felaniella usta & 1.5 & $-\quad 30$ & 3.5 & -15 & 5 & -44 & $1.5-$ \\
\hline 21. Axinopsida subquadrata & $6-$ & 62 & $4-$ & $-\quad 25$ & & & $4-62$ \\
\hline 22. Kellia japonica & & & 1 & -15 & 23 & -120 & $1-120$ \\
\hline 23. Mysella (?) sp. & & & & 15 & & & 15 \\
\hline 24. Cyclocardia crassidens & & & 32 & -50 & 100 & -150 & $32-150$ \\
\hline 25. Clinocardium californiense & $4-$ & $49[7,8]$ & $3-$ & -30 & & & $3-49$ \\
\hline 26. Clinocardium ciliatum & & & & 111 & & & 111 \\
\hline 27. Clinocardium likharevi & $45-$ & 62 & & 111 & & 100 & $45-111$ \\
\hline 28. Serripes groenlandicus & 17 & 62 & 4.5 & -111 & 60 & -120 & $4.5-120$ \\
\hline 29. Mactra chinensis & 1.5 & 16 & $9-$ & $-\quad 12$ & & 16 & $1.5-16$ \\
\hline 30. Spisula sachalinensis & 1.5 & -4 & & & & & $1.5-4$ \\
\hline 31. Raeta pulchella & $5-$ & 28 & 4.5 & $-\quad 25$ & & & $4.5-\quad 28$ \\
\hline 32. Cadella lubrica & $4-$ & 30 & & 6 & down & to 180 & $4-180$ \\
\hline 33. Macoma calcarea & 16 & $-\quad 62[9]$ & & 111 & 150 & -280 & $16-280$ \\
\hline 34. Macoma incongrua & 0 & -6 & & 11.5 & & & $0-11.5$ \\
\hline 35. Macoma scarlatoi & 10 & $-65[10]$ & 4.5 & -25 & & & $4.5-$ \\
\hline 36. Macoma golikovi & & & & 11 & & & 11 \\
\hline 37. Macoma middendorffi & & & & 7 & & & 7 \\
\hline 38. Nuttallia ezonis & & & $4-$ & $-\quad 7.5$ & & & $4-$ \\
\hline 39. Theora fragilis & $3-$ & $-\quad 18[11]$ & $4.5-$ & $-\quad 25$ & & & $3-$ \\
\hline 40. Siliqua alla & 10 & -20 & & 7.5 & & & $7.5-20$ \\
\hline 41. Mercenaria stimpsoni & 2 & 45 & $4-$ & $-\quad 9$ & & & $2-$ \\
\hline 42. Callithaca adamsi & $1-$ & -35 & 4 & 17.5 & 5 & -17 & $1-35$ \\
\hline 43. Protothaca jedoensis & & 1 & $3-$ & 7 & & & $1-7$ \\
\hline 44. Protothaca euglypta & 0 & $-\quad 1.5$ & $3-$ & $-\quad 18$ & 5 & $-\quad 15$ & $0-$ \\
\hline 45. Ruditapes philippinarum & 0 & $16[12]$ & $4-$ & 6 & & & $0-16$ \\
\hline 46. Liocyma fluctuosa & 23 & 65 & $4-$ & 47 & 60 & -220 & $4-220$ \\
\hline 47. Callista brevisiphonata & 2 & $-57[13]$ & $9-$ & -12 & 40 & -80 & $2-80$ \\
\hline
\end{tabular}


Table 3. (Continued)

\begin{tabular}{|c|c|c|c|c|}
\hline Species & Area I & Area II & Area III & In total \\
\hline 48. Mya truncata & & 11.5 & & 11.5 \\
\hline 49. Mya uzenensis & down to $20[14]$ & $4-9$ & & $4-20$ \\
\hline 50. Mya japonica & $1-14[15]$ & $4.5-17.5$ & & $1-17.5$ \\
\hline 51. Cryptomya busoensis & $5-$ & 18 & & $5-18$ \\
\hline 52. Anisocorbula venusta & $1-15[7]$ & $0.5-\quad 18$ & $20-40[16]$ & $0.5-40(840$ \\
\hline 53. Hiatella arctica & $0-150[17]$ & $2-111$ & $23-40$ & $0-150$ \\
\hline 54. Panomya norvegica & & $7.5-15$ & & $7.5-15$ \\
\hline 55. Agriodesma navicula & $1.5[18]$ & $2-15$ & & $0-15$ \\
\hline 56. Pandora pulchella & $4.5-57[7]$ & 11.5 & & $4.5-\quad 57$ \\
\hline 57. Pandora wardiana & & 111 & & 111 \\
\hline 58. Thracia itoi & 14 & 7 & & $7-14$ \\
\hline
\end{tabular}

Comments for Table 3:

a) Areas and References: Area I - Peter the Great Bay including Possjet Bay and area of the Far East State Marine Reserve (Razin, 1934; Golikov and Scarlato, 1967; Scarlato,1981; Moskaletz, 1984); Area II - present study (Vrangel Bay and middle Primorye); Area III - Moneron Island (Romeyko and Kamenev, 1985).

b) Data on bathymetric ranges include findings of both alive and dead (empty shells) mollusks.

c) Numerals in square brackets:

[1] - as Ennucula cyrenoides (Kuroda) in Golikov and Scarlato, 1967; [2] - as Nuculana pernula sadoensis (Yokoyama); [3] - as Yoldia keppeliana pseudonotabile Scarlato in Scarlato, 1981; [4] - as Modiolus difficilis (Kuroda et Habe); [5] - as Chlamys strategus (Dall); [6] -as Chlamys rosealbus Scarlato; [7] - depth range is given for entire Primorye coast; [8] - as Cardium (Cerastoderma) californiense Deshayes in Razin, 1934; [9] - as Macoma brota Dall in Moskaletz, 1984; [10] - as Macoma orientalis Scarlato; [11] - as Theora lubrica Gould; [12] - as Paphia philippinarum Adams et Reeve in Razin, 1934, and Venerupis japonica (Deshayes) in Golikov and Scarlato, 1967; [13] -including "Callista chinensis (Holten)" in Golikov and Scarlato, 1967; [14] - as Mya priapus Tilesius in Scarlato, 1981; [15] - as Mya arenaria japonica Jay in Golikov and Scarlato, 1967; [16] - Scarlato (1981) mentioned that A. venusta was found near Moneron Island in depth $84 \mathrm{~m}$; [17] -as Hiatella arctica orientalis (Yokoyama) in Golikov and Scarlato, 1967; [18] - as Entodesma naviculoides Yokoyama.

d) Empty cell means that this species is not found in this area or there are no exact data.

of them are known from coasts of Sakhalin and Hokkaido. These new records will make it possible to compare faunal properties in Far Eastern seas more precisely.

Analysis of bathymetric ranges of bivalve mollusks treated in our study and known from other localities of the Sea of Japan (Tables 3,4) seems to indicate the following tendencies. Some warm-water species (subtropical or subtropical-lowboreal according to zonal-geographical terminology) inhabit deeper areas in the south-eastern and south-western parts of the sea, but they are found in the north-western part only in the upper subtidal zone. For example, Acila insignis (Gould, 1861), Pandora wardiana A. Adams, 1859, Raeta pulchella (Adams et Reeve, 1848), C. lubrica and some others are known along the southern coast of Korea, Niigata Prefecture and Wakasa Bay of Japan at depths to 200-300 m, while they generally are not found below $30-40 \mathrm{~m}$ in north-western part of the Sea of Japan. The exception are the coastal waters of Moneron Island in the northern part of the sea influenced 
Table 4. Bathymetric ranges of bivalve mollusks obtained in present study and known from southern part of the Sea of Japan.

\begin{tabular}{|c|c|c|c|c|c|}
\hline Species & Area I & Area II & Area III & Area IV & In total \\
\hline Acila insignis & $104-210$ & & $121-137$ & $58-161$ & $58-210$ \\
\hline 2. Nuculana sadoensis & $143-145[1]$ & & & & $143-145$ \\
\hline 3. Yoldia johanni & & $93-96$ & & & $93-96$ \\
\hline 4. Arca boucardi & & & $11-210$ & $41-139$ & $11-210$ \\
\hline 5. Chlamys swifti & & & $101-108$ & 275 & $101-275$ \\
\hline 6. Parvamussium alaskense & & $278-518[2]$ & & & $278-518$ \\
\hline 7. Mizuhopecten yessoensis & & & $26-156[3]$ & $60-83[3]$ & $26-156$ \\
\hline 8. Felaniella usta & & & & $41-161$ & $41-161$ \\
\hline 9. Axinopsida subquadrata & $105-205$ & & $27-332$ & $58-161$ & $27-332$ \\
\hline 10. Clinocardium ciliatum & & & 225 & $130-180$ & $130-225$ \\
\hline 11. Serripes groenlandicus & & & $165-275$ & $157-198$ & $157-275$ \\
\hline 12. Mactra chinensis & & & $37-52$ & $60-94$ & $37-94$ \\
\hline 13. Raeta pulchella & & & $5-102[4]$ & $39-62[4]$ & $5-102$ \\
\hline 14. Cadella lubrica & & & $101-151$ & $67-125$ & $67-151$ \\
\hline 15. Macoma calcarea & & & $129-275$ & & $129-275$ \\
\hline 16. Theora fragilis & & & $34-56$ & & $34-56$ \\
\hline 17. Mercenaria stimpsoni & & & $100-210$ & $41-161$ & $41-210$ \\
\hline 18. Callithaca adamsi & & & & $87-161$ & $87-161$ \\
\hline 19. Protothaca jedoensis & & & $5-52$ & $126-139$ & $5-139$ \\
\hline 20. Cryptomya busoensis & & & $5-16$ & $80-161$ & $5-161$ \\
\hline 21. Anisocorbula venusta & & & $35-200$ & $41-125$ & $35-200$ \\
\hline 22. Hiatella arctica & & $93-96[5]$ & $5-275[5]$ & $41-175[6]$ & $5-275$ \\
\hline 23. Pandora wardiana & & & $11-300[7]$ & $41-200[7]$ & $11-300$ \\
\hline
\end{tabular}

Comments for Table 4:

a) Areas and references: Area I - Sea of Japan side of Korea (Je, 1993); Area II - Oki-Kaikyo Strait and off Hino-Misaki (Tsuchida and Hayashi, 1994); Area III - Niigata Prefecture (including Sado Isl.) (Ito, 1978, 1985, 1989); Area IV - Wakasa Bay and Hyogo Prefecture (Ito, 1967, 1990).

b) Data on bathymetric ranges include findings of both alive and dead (empty shells) mollusks.

c) Numerals in square brackets:

[1] - as Nuculana pernula sadoensis (Yokoyama); [2] - as Polynemamussium alaskense (Dall); [3] - as Patinopecten (Mizuhopecten) yessoensis (Jay); [4] - as Raetellops pulchella (Adams et Reeve); [5] - as Hiatella orientalis (Yokoyama); [6] - including Hiatella orientalis (Yokoyama); [7] - as Pandorella wardiana (Adams) in Ito, 1990.

d) Empty cell means that this species is not found in this area or there are no exact data.

by a warm branch of Tsushima Current where some subtropical-lowboreal species can be found to $100 \mathrm{~m}$ (Romeyko \& Kamenev, 1985). The same feature can be demonstrated for cold-water species inhabiting deeper areas in the southern part of the Sea of Japan (see Tables 3,4). Nishimura (1966) recognized several animal communities characterized by their distinctive faunal composition and their regular position in the vertical distribution in the sea. For example, his so-called taraba I community (subarctic sublittoral community) occupies a depth range of $150-250 \mathrm{~m}$ in the eastern and southern regions and inhabits shallow $(5-60 \mathrm{~m})$ coastal zones in the northern and north-western regions. This clearly 
shows that the general tendency of submergence of relatively cold-water animals into deeper areas at the edge of their ranges can be applied to the Sea of Japan molluscan fauna. On the other hand, warm-water mollusks also submerge into deeper areas in southern part of the sea. This reflects a peculiar character of complicated current systems: the Sea of Japan is divided into two distinct areas - the south-eastern warm area washed by the Tsushima Current, and the north-western cold area affected by the Liman and Primorskoye Current (Nishimura, 1983). Further faunal studies will clarify in detail the complex biogeographical nature of the Sea of Japan.

It should be mentioned that molluscan assemblage from sta. 39 (depth $111 \mathrm{~m}$ ), most likely, contains some subfossil shells (Macoma calcarea (Gmelin, 1791), Macoma middendorff Dall, 1885). This sample was taken on a muddy sand bottom with numerous pebbles. Pebbly deposits are widely distributed along the coast of Primorye (so-called Primorian gravel belt in the low-subtidal zone and represent traces of an ancient Late Plestocene coastline recognized by many geologists since 1950 (Zabelin et al., 1975; Mechetin \& Ryazantsev, 1978). Taphonomic conditions of the shells prove their subfossil origin. This fact should be taken into account when considering bathymetric ranges of bivalve mollusks in the north-western part of the Sea of Japan. Evseev (1981) clearly showed that the present-day and Holocene depth distributions of some bivalve species are significantly different depending on post-glacial sea level rise. Another reason for the wide depth ranges of empty shells (as well as unusual local distribution) is the redeposition of subfossil remains resulting from the erosional action of rivers. Lutaenko (1992) studied this process on the coasts of Amur and Ussuri Bays in respect to erosion of the mid-Holocene deposits with abundant species of the genus Anadara - Anadara inaequivalvis (Bruguiere, 1789), became extinct in the Late Holocene and can be used as a reliable indicator of asynchronous transportation. Among different aspects of this process, we would like to emphasize ice dispersal, i.e., freezing of shells and their fragments (both Recent and subfossil) to the lower surface of shore ice and its further transportation, primarily from semi-enclosed bays to open areas. Razin (1934) observed empty shells of oysters at a depth of $36 \mathrm{~m}$ in Ussuri Bay while alive oyster settlements occur in the bathymetric range of $0.5-7 \mathrm{~m}$ (Razin, 1934; Scarlato, 1981) in Peter the Great Bay. Razin (1934, p. 41) explained this phenomenon by the ice dispersal based on his direct observations of the oyster shells during $1924-1932$ along the coast of Amur Bay. We found in Possjet Bay rare valves of an estuarine species, Corbicula japonica Prime, 1864 (Corbiculidae) in beach drift of open areas which were most likely transported from river mouths situated at a distance of $10-15 \mathrm{~km}$ (Lutaenko, 1990; 1994b). It is suggested that the unusually wide depth ranges of Mytilus edulis L., $1758(7.5-25 \mathrm{~m})$ and Crassostrea gigas (Thunberg, 1793) $(4-25 \mathrm{~m})$ represented by empty shells in Vrangel Bay, might be explained by the same reasons. $M$. edulis inhabits mainly the intertidal zone in Peter the Great Bay influenced by winter shore ice, or its shells originate from biofouling communities in Port Vostochny.

\section{Acknowledgements}

Thanks are due to Dr. Eugene I. Schornikov, Mrs. Anna A. Lykova, Mr. Alexey V. Kasatkin (Institute of Marine Biology, FEB RAS), and Mr. Dmitry A. Sokolenko (Far East State University) for their help during the 18th cruise of the $R / V$ Akademik Oparin. Extensive sampling with SCUBA-diving was made by Dr. Yuri M. Yakovlev (IMB) to whom my special thanks. All samples from Vrangel Bay were placed at my disposal by Dr. E.I. Schornikov and Dr. Ivan Arzamastsev (Primorye Institute of Aquaculture). Dr. Gennady M. Kamenev (IMB) kindly checked my identifications of Thyasiridae. Part of photographs were taken by Mr. Alexander A. Omelyanenko, an illustration of Chlamys cf. behringiana was drawn by Mrs. Elvira S. Schornikova 
(IMB). I am grateful to Dr. Jong-Geel Je (Korea Ocean Research and Development Institute) for support and providing facilities, Dr. Eugene V. Coan (California Academy of Sciences) for comments on dates of publications of some species, and to Ms. Tatyana N. Koznova (IMB) and Mr. Victor Starostka (formerly, Far East State Marine Reserve) for improving the English text. This work was partly supported by grants N 96-05-64086 and N 98-04 49362a from Russian Foundation of Basic Researches (RFFI). Anonymous reviewers provided useful comments on content of the manuscript.

\section{References}

Amano, K. 1996. Taxonomy and distribution of boreal species of Macoma (Bivalvia) from the Plio-Pleistocene strata in the Japan Sea borderland. Bull. Joetsu Univ. Educ., 16(1): 289-298. (in Japanese)

Bartsch, P. 1929. Report upon the collection of marine mollusks made by Professor Dr. K. Derjugin in the Gulf of Peter the Great. Expl. Mers d'U.S.S.R., 10: 129-140.

Biryulin, G.M., Mikulich, L.V., Biryulina, M.G. \& Yakunin, L.P. 1970. Summer modifications of the waters of Peter the Great Bay. Trans. Far East. Res. Hydrometeorol. Inst., 30: 286-299. [in Russian]

Coan, E.V. 1971. The Northwest American Tellinidae. Veliger, suppl. 14: 1-63.

Coan, E.V. \& Scott, P.H. 1997. Checklist of the marine bivalves of the northeastern Pacific Ocean. Santa Barbara Mus. Natur. Hist. Contrib. Sci., 1: 1-28.

Darkina, S.M. \& Lutaenko, K.A. 1996. Catalogue of the collection of bivalve mollusks in the Zoological Museum, Far East State University, Vladivostok. Kor. J. Malacol., 12 (1): 53-83.

Dodd, J.R. \& Stanton, R.J. 1981. Paleoecology, concepts and applications. 559 pp. J. Wiley \& Sons, New York.

Evseev, G.A. 1976. The origin of the Vostok Bay (the Sea of Japan) and the history of its fauna of bivalves. In: V.L. Kasyanov (ed.), Biological Investigations in the Vostok Bay, pp. 23-62. DVNTs AN SSSR, Vladivostok. [in Russian]

Evseev, G.A. 1981. Communities of bivalve mollusks in post-glacial deposits of shelf of the Sea of Japan. 160 pp. Nauka, Moscow. [in Russian, title translated]

Fedorov, V.V. 1991. Bottom landscapes of the shelf of the southeast Primorie (the Sea of Japan). In: A.A. Neyman (ed.), Biotopic Basic of the Distribution of Commercial and Food Marine Animals, pp. 70-82. VNIRO, Moscow. [in Russian]

Golikov, A.N. \& Scarlato, O.A. 1967. Molluscs of the Possjet Bay (the Sea of Japan) and their ecology. Trans. Zool. Inst., USSR Acad. Sci., 42: 5-154. [in Russian]

Golikov, O.A. \& Scarlato, O.A. 1971. On the fauna of molluscs from the Possjet Bay of the Sea of Japan. Explor. Fauna Seas, 8 (16): 188-205. [in Russian]

Golikov, A.N. \& Scarlato, O.A. 1985. Shell-bearing gastropod and bivalve mollusks of the southern Sakhalin shelf and their ecology. Explor. Fauna Seas, 30 (38): 368-487. [In Russian]

Habe, T. 1977. Systematics of Mollusca in Japan. Bivalvia and Scaphopoda. 372 pp. Hokuryukan Publ. Co., Tokyo. [in Japanese]

Hidaka, K. 1966. Japan Sea. In: R.W. Fairbridge (ed.), The encyclopedia of Oceanography, pp. 417-424. Van Nostrand Reinhold Co., New York, etc.

Hong, J.-S., Seo, I.-S., Yoo, J.-W. \& Jung, R.H. 1994. Soft-bottom benthic communities in North Port, Inchon, Korea. Nature Conservation, 88: 34-50. [in Korean]

Ignatova, V.F. \& Chudaeva, V.A. 1983. Hard drainage of rivers and sediments of the shelf of the Sea of Japan. 154 pp. DVNTs AN SSSR, Vladivostok. [in Russian, title translated]

Ito, K. 1967. A catalogue of the marine molluscan shell-fish collected on the coast of and off Tajima, Hyogo Prefecture. Bull. Japan Sea Reg. Fish. Res. Lab., 18: 39-91. [in Japanese]

Ito, K. 1978. The distribution of shell remains in the Mano Bay of Sado Island and its vicinity. Bull. Japan Sea Reg. Fish. Res. Lab., 29: 201-227. [in Japanese]

Ito, K. 1985. Distribution of the molluscan shells in the surrounding areas of Sado and Awa Isls, Niigata Prefecture. Bull. Japan Sea Reg. Físh. Res. Lab., 35: 23-127. [in Japanese] 
Ito, K. 1989. Distribution of molluscan shells in the coastal areas of Chuetsu, Kaetsu and Sado Island, Niigata Prefecture, Japan. Bull. Japan Sea Reg. Fish. Res. Lab., 39: 37-133. [in Japanese]

Ito, K. 1990. Distribution of molluscan shells in Wakasa Bay, Japan Sea. Bull. Japan Sea Natl. Fish. Res. Inst., 40: 79-211. [in Japanese]

Ivanova, M.B. 1985. On the fauna of bivalve mollusks of the intertidal zone of Moneron Island. In: O.G. Kussakin (ed.), Benthos of the Moneron Island Shelf, pp. 81-84. DVNTs AN SSSR, Vladivostok. [in Russian, title translated]

Ivanova, M.B. \& Moskaletz, I.P. 1984. Two new species of bivalve mollusks of the family Thyasiridae from the area of Far East State Marine Reserve. In: V.S. Levin (ed.), Animal World of the Far East Marine Reserve, pp. 45-50. DVNTs AN SSSR, Vladivostok. [in Russian, title translated]

Ivaschenko, E.A. 1993. Circulation of waters of Peter the Great Bay. In: V.S. Petrenko (ed.), Geographical Investigations of Shelf of the Far Eastern Seas, pp. 31-61. Far East State Univ. Press, Vladivostok. [in Russian, titla translated]

Je, J.-G. 1993. Distribution of molluscs in soft bottom of Korean seas. 296 pp. Ph.D. Thesis, Seoul Nat. Univ., Seoul. [in Korean]

Kafanov, A.I. 1981. Revision of the genus Ciliatocardium Kafanov, 1974 (Bivalvia, Cardiidae). Trans. Inst. Mar. Biol., Far East Sci. Centre, USSR Acad. Sci., 24: 43-61. [in Russian, title translated]

Kafanov, A.I. 1991. Shelf and continental slope bivalve molluscs of the Northern Pacific Ocean: A check-list. 198 pp. DVO AN SSSR, Vladivostok. [in Russian]

Kafanov, A.I. \& Lutaenko, K.A. 1996. New data on the bivalve mollusc fauna of the North Pacific Ocean. 2. On the status and taxonomic position of some Tellinidae. Ruthenica (Russ. Malacol. J.), 6 (1): 11-21. [in Russian]

Kafanov, A.I. \& Lutaenko, K.A. 1997a. Primary homonymy of two species of the genus Macoma Leach, 1819 (Bivalvia, Tellinidae). Bull. Inst. Malacol., Tokyo, 3(4): 51-54.

Kafanov, A.I. \& Lutaenko, K.A. 1997b. New data on the bivalve mollusc fauna of the North Pacific Ocean. 3. On some species ofthe subfamily Dosininae (Veneridae). Ruthenica (Russ. Malacol. J.), 7 (2): 149-153. [in Russian]

Kafanov, A.I., \& Lutaenko, K.A. (in press) New data on the bivalve mollusc fauna of the North Pacific Ocean. 5. Notes on the Callista trigonoovata Scarlato in Volova et Scarlato, 1980 (Veneridae). Ruthenica (Russ. Malacol. J.) [in Russian]

Kamenev, G.M. 1990. A new species of the genus Macoma (Bivalvia, Tellinidae) from the Kraternaya Bay (Yankitch Island, Kuril Isls). Zool. Zh., 69 (3): 127-132. [in Russian]

Kamenev, G.M. 1995. Species composition and distribution of bivalve mollusks on the Commander Islands shelf. Malacol. Rev., 28: 1-23.

Kamenev, G.M. 1996. Additional data on morphology and geographic distribution of Adontorhina cyclia Berry, 1947 (Bivalvia: Thyasiridae), newly reported from the Northwestern Pacific. Veliger, 39 (3): 213-219.

Klimova, V.L. 1974. On year-to-year changes of bottom fauna on the shelf of the central part of Peter the Great Bay (the Sea of Japan). Okeanol., 14 (1): 173-175. [in Russian]

Klimova, V.L. 1975. Changes in the distribution of mollusc Liocyma fluctuosa in the Peter the Great Bay for many years. Okeanol., 15 (3): 528-530. [in Russian]

Korotky, A.M. \& Khudyakov, G.I. 1990. Exogenic geomorphological systems of the sea coast. 216 pp. Nauka, Moscow. [in Russian, title translated]

Korotky, A.M., Karaulova, L.P. \& Troitskaya, T.S. 1980. Quaternary deposits of Primorye. Stratigraphy and paleogeography. Trans. Inst. Geol. \& Geophys., Siberian Branch, USSR Acad. Sci., 429: 1-234. [in Russian, title translated]

Lim, H.-S., Hong, J.-S. \& Je, J.-G. 1995. Abundance and distribution pattern of the semelid bivalve, Theora fragilis A. Adams in Chinhae Bay, Korea. Kor. J. Malacol., 11 (1): 21-34. [in Korean]

Lutaenko, K.A. 1990. Bivalve mollusks from the beach zone of Peter the Great Bay (Sea of Japan). IMB, FEB USSR Acad. Sci., preprint N 28: 1-51. [in Russian, title translated]

Lutaenko, K.A. 1991. On the origin of warm-water elements of malacofauna of Peter the Great Bay, Sea of Japan. Biol. Morya, 1: 12-20. [in Russian] (English translation: Sov. J. Mar. Biol., 
$1991,17(1): 7-12)$

Lutaenko, K.A. 1992. Comidological differentiation of heterochronous shells in the coastal zone of the sea. Palcontol. Zh., 4: 64-66. [in Russian] (English translation: Paleontol. J., 1992, 26 (4): 79-82)

Lutaenko, K.A. 1993. Subfamily Anadarinae (Bivalvia: Arcidae) of the Russian Far East coast. Korean J. Malacol., 9 (1): 27-32.

Lutaenko, K.A. 1994a. Actuopaleontological study of beach thanatocoenoses of bivalved mollusks on the coast of the Sea of Japan. Paleontol. Zh., 2: 21-30. [in Russian]

Lutaenko, K.A. 1994b. Beach molluscan thanatocoenoses in Possjet Bay, Sea of Japan: comparison between open and sheltered beaches. Benthos Res., 47: 1-12.

Matsukuma, A., Ito, K., Igarashi, S. \& Takagawa, K. 1991. Taxonomy and zoogeography of some remarkable bivalves and chitons of northern Hokkaido, Japan. Mem. Nat. Sci. Mus., Tokyo, 24: $67-80$.

Mechetin, A.V. \& Ryazantsev, A.A. 1978. On the gravel of the outer zone of shelf of south Primorye. In: N.P. Vasilkovsky (ed.), Geology of the Floor of Japan and Philippine Seas, pp. 58-61. DVNTs AN SSSR, Vladivostok. [in Russian, title translated]

Moskaletz, I.P. 1984. On the fauna of bivalve mollusks of the Far East State Marine Reserve. In: V.S. Levin (ed.), Animal World of the Far East State Marine Reserve, pp. 30-44. DVNTs AN SSSR, Vladivostok. [in Russian, title translated]

Moskaletz, I.P. 1990. Zonal-geographical composition and distribution of bivalve mollusks in soft bottom in the subtidal zone of the Far East Marine Reserve. In: V.V. Gulbin (ed.), Systematics and Fcology of Hydrobionts of the Far East Marine Reserve, pp. 124-130. DVO AN SSSR, Vladivostok. [in Russian, title translated]

Myasnikov, V.G., Zgurovsky, K.A. \& Temnych, O.S. 1992. Morphological differentiation of commercial scallops of the genus Chlamys (Bivalvia, Pectinidae) in north-western Pacific Ocean. Zool. Zh., 71 (9): 22-32. [in Russian]

Nishimura, S. 1966. The zoogeographical aspects of the Japan Sea. Part III. Publ. Seto Mar. Biol. Lab., 13 (5): 365-384.

Nishimura, S. 1983. Okhotsk Sea, Japan Sea, East China Sea. In: B.H. Ketchum (ed.), Ecosystems of the World 26. Estuaries and Enclosed Seas, pp. 375-401. Elsevier, Amsterdam, etc.

Papunov, V.G. 1987. Bottom natural complexes of the upper shelf of middle Primorye. In: B.V. Preobrazhensky (ed.), Bottom Landscapes of the Sea of Japan, pp. 73-81. DVO AN SSSR, Vladivostok. [in Russian, title translated]

Podorvanova, N.F., Ivashinnikova, T.S., Petrenko, V.S. \& Khomichuk, L.S. 1989. Main features of hydrochemistry of Peter the Great Bay (Sea of Japan). 201 pp. DVO AN SSSR, Vladivostok. [in Russian, title translated]

Rakov, V.A. \& Lutaenko, K.A. 1997. The Holocene molluscan fauna from shell middens on the coast of Peter the Great Bay (Sea of Japan): paleoenvirommental and biogeographical significance. West. Soc. Malacol., Annual Rept., 29: 18-23.

Razin, A.I. 1934. Marine commercial molluscs of the southern part of the Maritime Province of the Soviet Far East. Bull. Pacific Sci. Inst. Fish., 8: 1-110. [in Russian]

Romeyko, L.V. 1985. Zonal-biogeographical structure of the fauna of bivalve mollusks of northern part of the Sea of Japan. In: A.I. Kafanov (ed.), Benthos and Conditions of Its Existence in Shelf Zones of Sakhalin, pp. 86-91. DVNTs AN SSSR, Vladivostok. [in Russian, title translated]

Romeyko, L.V. \& Kamenev, G.M. 1985. Bivalve mollusks of the subtidal zone of Moneron Island. In: O.G. Kussakin (ed.), Benthos of the Moneron Island Shelf, pp. 85-101. DVNTs AN SSSR, Vladivostok. [in Russian, title translated]

Rynkov, V.S., Shakhgeldjan, I.G. \& Polishuk, L.N. 1974. Quaternary deposits of the coastal part of the Peter the Great Bay. In: N.P. Vasilkovsky and B.Ya. Karp), The Problems of Geology and Geophysics of the Marginal Seas of North-Western Part of the Pacific Ocean, pp. 76-87. DVNTs AN SSSR, Vladivostok. [in Russian]

Scarlato, O.A. 1960. Bivalve mollusks of the Far Eastern seas of the USSR (Order Dysodonta). Opred. Faune SSSR, izd. Zool. Inst. AN SSSR, 71: 1-151. [in Russian, title translated] 
Scarlato, O.A. 1972. New species of Cuspidariidae (Septibranchia, Bivalvia) from the seas of Soviet Far East. Trans. Zool. Inst., USSR Acad. Sci., 52: 121-128. [in Russian]

Scarlato, O.A. 1981. Bivalve mollusks of temperate latitudes of the western portion of the Pacific Ocean. Opred. Faune SSSR, izd. Zool. Inst. AN SSSR, 126: 1-479. [in Russian, title translated]

Scarlato, O.A. \& Kafanov, A.I. 1988. Contribution to the fauna of bivalve mollusks in the USSR Far East Seas. Zool. Zh., 67 (6): 937-942. [In Russian]

Stepanov, V.V. 1976. Water temperature and salinity characteristics of the Vostok Bay (Sea of Japan). In: V.L. Kasyanov (ed.), Biological Investigations in the Vostok Bay, pp. 12-22. DVNTs AN SSSR, Vladivostok. [in Russian]

Taira, K. 1995. Holocene paleoceanographic changes in Japan and neighboring regions. J. Coast. Res., Spec. Iss. 17: 153-154.

Taira, K. \& Lutaenko, K.A. 1993. Holocene palaeoceanographic changes in the Sea of Japan. Rept. Taisetsuzan Inst. Sci., Hokkaido Univ. Educ., 28: 65-70. [in Japanese]

Tsuchida, E. \& Hayashi, I. 1994. Characteristics of lower-sublittoral and bathyal molluscs in the western (sic!) area of the Sea of Japan. Bull. Japan Sea Natl. Fish. Res. Inst., 44: 81-129. [in Japanese]

Volova, G.N. \& Scarlato, O.A. 1980. Bivalve mollusks of Peter the Great Bay. 95 pp. DVNTs AN SSSR \& DVGU, Vladivostok. [in Russian, title translated]

Yokoyama, H., Toda, S., Abo, K. \& Yamamoto, S. 1996. Macrobenthic fauna of Gokasho Bay: comparison of 1993 and 1941 surveys. Bull. Natl. Inst. Aquacult., 25: 23-42. [in Japanese]

Yurasov, G.I. \& Yarichin, V.G. 1991. Currents of the Sea of Japan. 174 pp. DVO AN SSSR, Vladivostok. [in Russian, title translated]

Zabelin, V.V., Chaynikov, V.I. \& Gramm-Osipov L.M. 1975. On the origin of bottom deposits of shelf of the Sea of Japan near the coast of north-eastern Primorye. Trans. Pacific Oceanol. Inst., Far East Sci. Centre, USSR Acad. Sci., 7: 112-114. [in Russian, title translated] 


\section{Explanations to Plates I-II}

Plate I

Figs. 1, 2. Chlamys (Chlamys) of. behringiana (Middendorff, 1849). Left and right valves, length 40 mm. Sea of Japan, middle Primorye, sta. 39, depth $111 \mathrm{~m}$. MIMB.

Fig. 3. Chlamys (Chlamys) cf. behringiana (Middendorff, 1849). Right valve, length $56 \mathrm{~mm}$. Sea of Japan, middle Primorye, sta. 39, depth $111 \mathrm{~m}$. MIMB.

Fig. 4. Macoma (Macoma) middendorfi Dall, 1885. Right valve, length $36 \mathrm{~mm}$. Sea of Japan, Peter the Great Bay, Boysman Bay, beach drift. ZMFU no. $11120 / \mathrm{Bv}-1220$.

Fig. 5. Chlamys (Chlamys) chosenica Kuroda, 1932. Left valve, length $66 \mathrm{~mm}$. Sea of Japan, middle Primorye, sta. 39, depth $111 \mathrm{~m}$. MIMB.

Fig. 6. Mya (Mya) truncata L., 1758. Right valve, length $60 \mathrm{~mm}$. Sea of Japan, Nakhodka Bay, Vrangel Bay, sta. 19, depth $11.5 \mathrm{~m}$. MIMB.

Plate II

Fig. 1. Macoma (Macoma) middendorff Dall, 1885. Right valve, length $34 \mathrm{~mm}$. Sea of Japan, Peter the Great Bay, Popov Island, beach drift. ZMFU no. $10147 / \mathrm{Bv}-582$.

Fig. 2. Panomya norvegica (Spengler, 1793). Left valve, length $43 \mathrm{~mm}$. Sea of Japan, Nakhodka Bay, Vrangel Bay, sta. 14,depth $7.5 \mathrm{~m}$. MIMB.

Fig. 3. Liocyma fluctuosa (Gould, 1841). Right valve, length27 mm. Sea of Japan, Nakhodka Bay, Vrangel Bay, sta. 14, depth $7.5 \mathrm{~m}$. MIMB.

Fig. 4. Clinocardium (Keenocardium) californiense (Deshayes, 1839). Left valve, length $37 \mathrm{~mm}$. Sea of Japan, Nakhodka Bay, Vrangel Bay, sta. 29, depth $12.5 \mathrm{~m}$. MIMB.

Fig. 5. Serripes groenlandicus (Mohr, 1786). Left valve, length $66 \mathrm{~mm}$. Sea of Japan, Nakhodka Bay, Vrangel Bay, sta. 17, depth $11.5 \mathrm{~m}$. MIMB.

Fig. 6. Nuttallia ezonis (Kuroda et Habe, 1955). Left valve, length $28 \mathrm{~mm}$. Sea of Japan, Nakhodka Bay, Vrangel bay, sta. 18, depth $4 \mathrm{~m}$. MIMB.

Figs. 7, 10. Pandora (Heteroclidus) pulchella Yokoyama, 1926. Right and left valves, length 43 mm. Sea of Japan, Nakhodka Bay, Vrangel Bay, sta. 17, depth $11.5 \mathrm{~m}$. MIMB.

Fig. 8. Macoma (Macoma) scarlatoi Kafanov et Lutaenko, 1997. Right valve, length $36 \mathrm{~mm}$. Sea of Japan, Nakhodka Bay, Vrangel Bay, sta. 25, depth $12.5 \mathrm{~m}$. MIMB.

Fig. 9. Thracia itoi Habe, 1961. Right valve, length $43 \mathrm{~mm}$. Sea of Japan, Nakhodka Bay, Vrangel Bay, sta. 31, depth $7 \mathrm{~m}$. MIMB.

Fig. 11. Macoma (Macoma) golikovi Scarlato et Kafanov, 1988. Right valve, length $35 \mathrm{~mm}$. Sea of Japan, Nakhodka Bay, Vrangel Bay, sta. 5, depth $11 \mathrm{~m}$. MIMB. 
Publ. Seto Mar. Biol. Lab., 38(5/6), 1999

Plate I

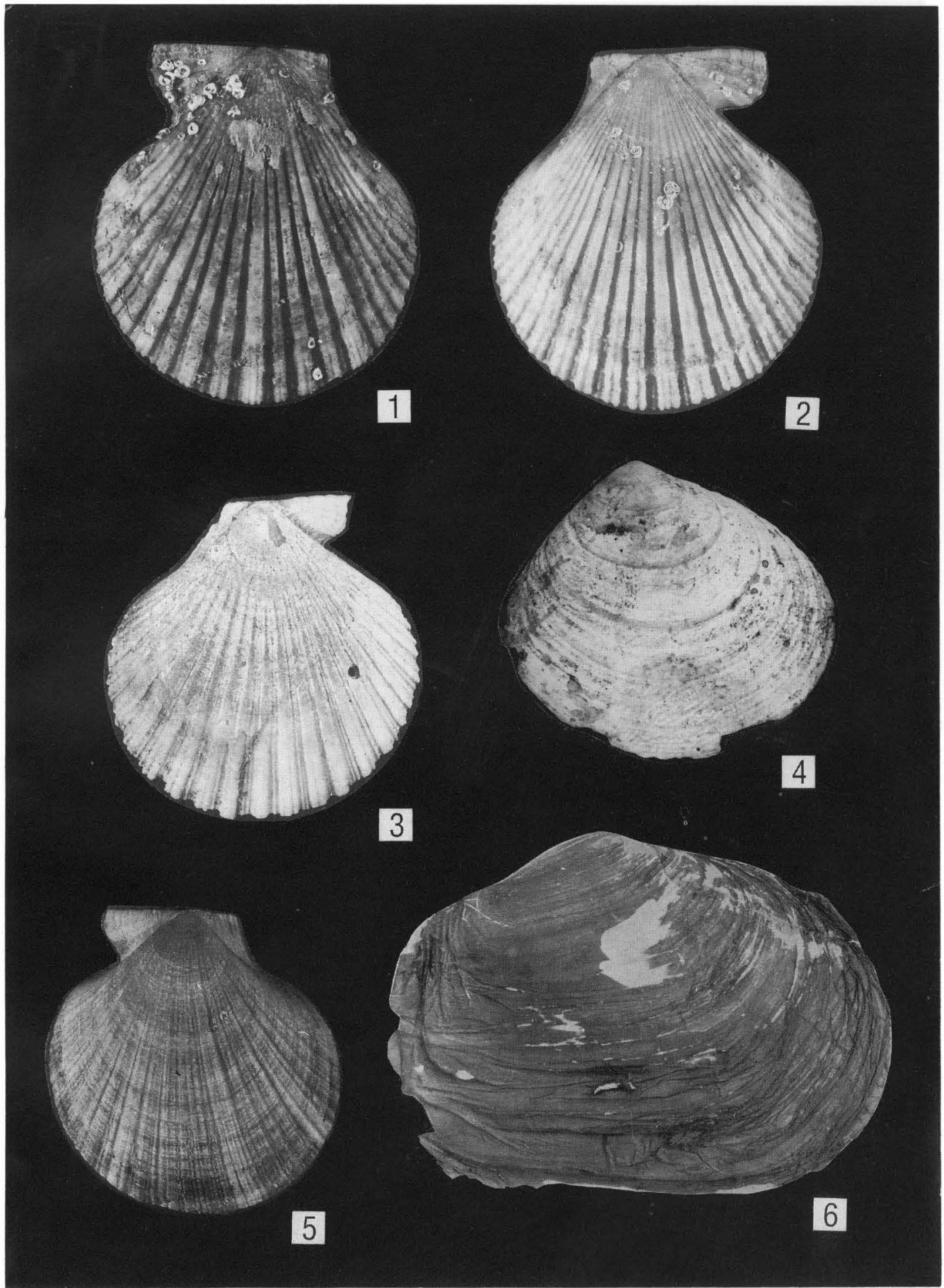


Publ. Seto Mar. Biol. Lab., 38(5/6), 1999

Plate II

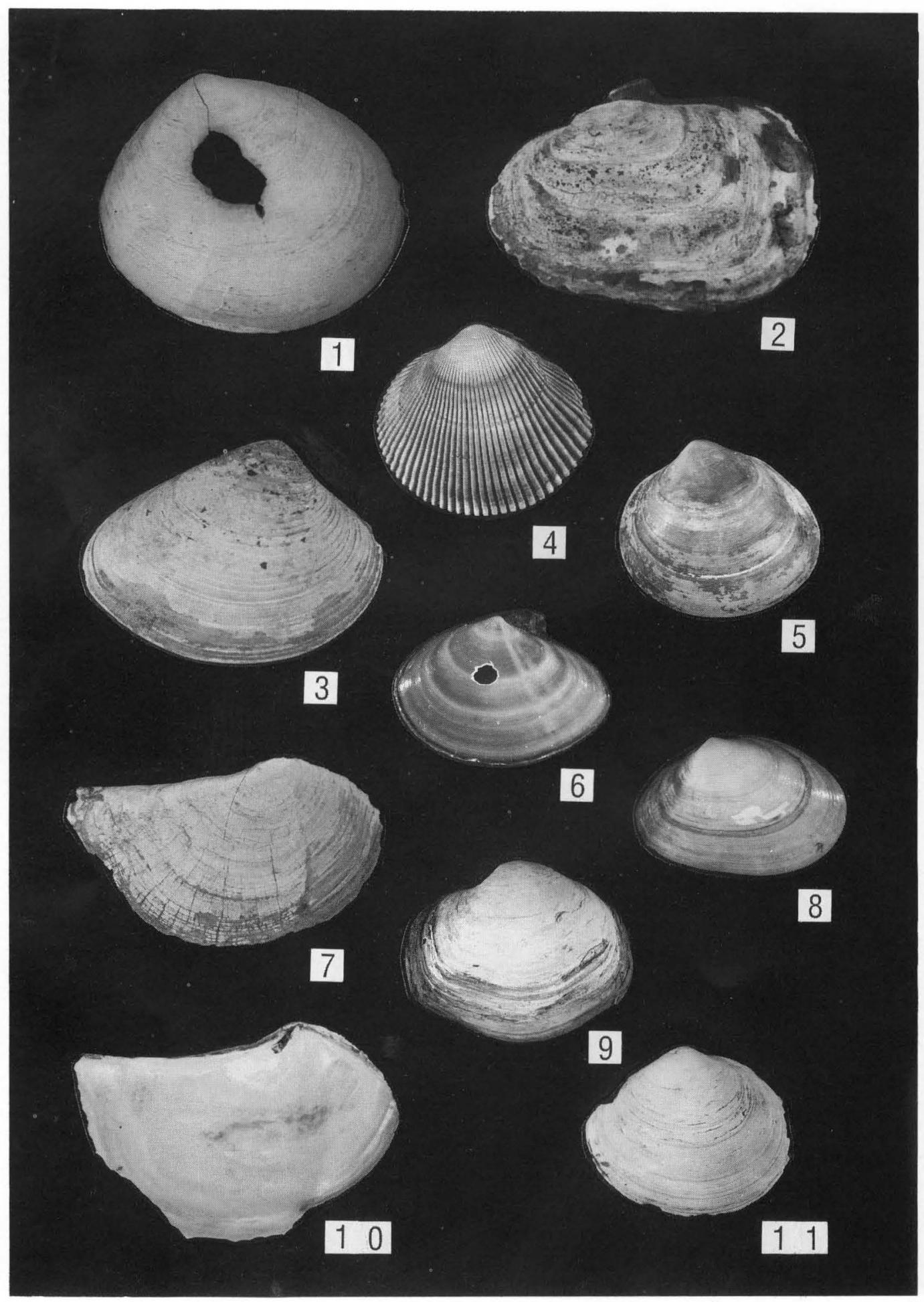

